\title{
COMPARAÇÃO ENTRE FONTES DE FÓSFORO ATRAVÉS DE TRÊS EXTRATORES QUÍMICOS DO SOLO E PLANTAS DE ARROZ
}

\section{REYNALDO ROCHA BELTRÁN}

Engenheiro agrônomo

Orientador: Prof. Dr. Ronaldo Ivan Silveira

Dissertação apresentada à Escola Superior de Agricultura "Luiz de Queiroz", da Universidade de São Paulo, para a obtenção do título de Mestre em Agronomia. Área de concentração: Solos e Nutrição de Plantas

PIRACICABA

Estado de São Paulo - Brasil

Setembro - 1994 
Ficha catalogretica preparada pela Seçăo de Livros da Divisă de Fiblioteca e Documentaçăo - FCLQ/USF

Fucha beltrar, Feyraldo

Ro72c Comparaça entre fontes de fosforo atraves de tres extratores quimicos do solo e plantas de arroz.

Firacicaba, 1994.

$73 p$.

Diss. (Mestre) ESALE

Eibliografia.

1. Arroz - Adubaça fostatada 3. Fasforo em 5010

5. Extrator químico I. Escola Superior de Agricultura

Luiz de Gueiroz, Firacicata

CDD $\quad 633.18$

6.1 .55 
COMPARAÇÃO ENTRE FONTES DE FÓSFORO ATRAVÉS DE TRÊS EXTRATORES QUÍMICOS DO SOLO E PLANTAS DE ARROZ

\section{REYNALDO ROCHA BELTRÁN}

Aprovado em: 3 de novembro de 1994

\section{Comissão julgadora:}

Prof. Dr. Ronaldo Ivan Silveira

ESALQ/USP

Prof. Dr. Quirino Augusto de Camargo Carmello

. ESALQ/USP

Prof. Dr. Iraê.Amaral Gerrini

UNESP/BOT

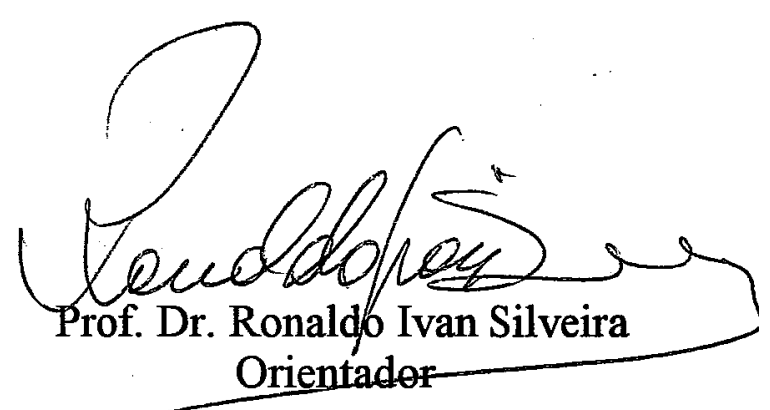


A mis amados papás, Gerardo y Daria que siempre se esfuerzan para darme todo lo mejor, com profundo agradecimiento

A mi esposa y compañera que siempre me apoya en todo momento, com mucho amor

A mis hermanos, Felix y Willma y a mi sobrina Angie por los
momentos compartidos, con cariño

A mi abuelita Simona, com mucha nostalgia

(in memoriam)

DEDICO

A mi amada hija Maristela, la razón de mi existir con mucho amor

OFRESCO 
A Deus por tudo que me concede na vida

Aos meus pais Gerardo e Daria pelo amor, motivação e apoio constante para me tornar em um homem de bem.

A Marli minha esposa, pelo incentivo, paciência e colaboração na realização deste trabalho

À ESALQ/USP, pela oportunidade de realizar o curso e pela acolhida

À Embaixada do Brasil na Bolívia e a CAPES/PEC/PG pela bolsa concedida

Ao Dr. Ronaldo Ivan Silveira pelos conselhos e pela valiosa orientação

Aos funcionários do Dpto. de Ciência do Solo y do CIAGRI da ESALQ/USP, pela colaboração na realização das análises e ao amigo Miltinho pela colaboração na elaboração das figuras

Aos meus amigos, Raimundo Nonato Assis Jr., Rivaldo Vital dos Santos, José R. N. Ferreira Gama, José Simplicio de Holanda, Antônio Saraiva Muniz, Marcos Cabral, José Rafael Baldeón Mendez e Juan Carlos Montaño, pela colaboração desinteresada na realização deste trabalho

A todos os amigos e colegas do curso de Pós-Graduação em Solos e Nutrição de Plantas da ESALQ/USP, pelo excelente convivio 


\section{SUMÁRIO}

Página

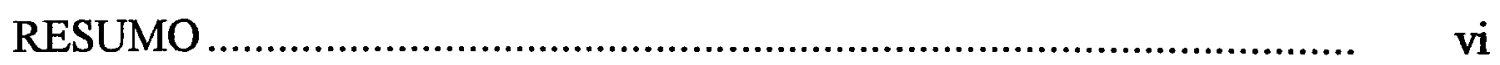

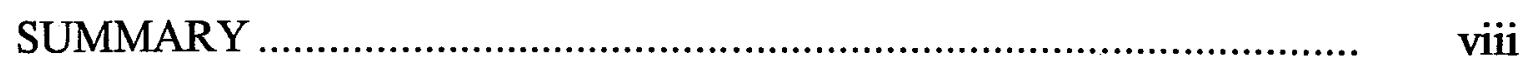

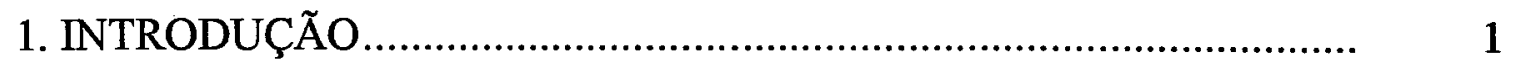

2. REVISÃO DE LITERATURA........................................................ 4

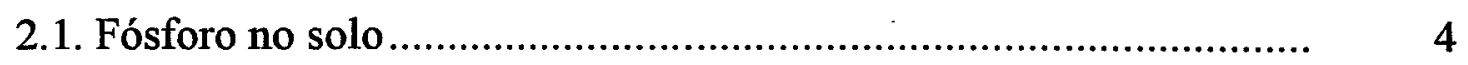

2.2. Fósforo na planta ......................................................................

2.3. Comparação entre fontes de fósforo …............................................ 10

2.4. Avaliação da disponibilidade de fósforo ......................................... 14

2.5. Influência do tempo de incubação na extração de $P$........................ 17

3. MATERIAL E MÉTODOS........................................................... 20

3.1. Amostragem e preparo do solo..................................................... 20

3.2. Localização do experimento......................................................... 20

3.3. Instalação e condução do experimento .......................................... 21

3.4. Análises químicas da planta e do solo ........................................... 23

3.5. Avaliação dos tratamentos ............................................................ 24

4. RESULTADOS E DISCUSÃO ....................................................... 25

4.1. Análise do solo antes da semeadura do arroz ............................... 25

4.2. Resposta das plantas de arroz às doses e fontes de fósforo............. 27

4.3. Fósoforo recuperado do solo pelos extratores Mehlich-1, Olsen e

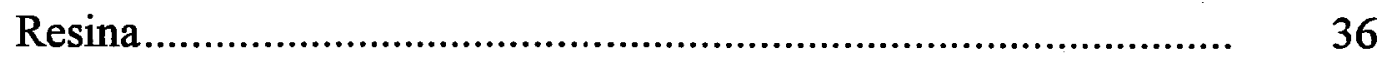

4.4.Resposta do arroz ao fósforo recuperado pelos extratores ................ 43

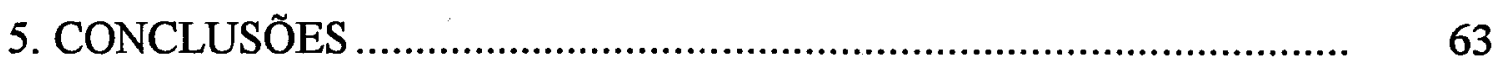

REFERÊNCIAS BIBLIOGRÁFICAS .............................................. 65 


\title{
COMPARAÇÃO ENTRE FONTES DE FÓSFORO ATRAVÉS DE TRÊS EXTRATORES QUIMICOS DO SOLO E PLÁNTAS DE ARROZ
}

\author{
Autor: Reynaldo Rocha Beltrán \\ Orientador: Prof. Dr. Ronaldo Ivan Silveira
}

\section{RESUMO}

A disponibilidade de fósforo no solo foi avaliada em experimento realizado em casa de vegetação, utilizando amostras de um solo Areia Quartzosa, do Bairro de Riberão Claro, Piracicaba - S.P..

Utilizou-se cinco adubos fosfatados: fosfato natural Alvorada, fosfato monoamônio, superfosfato simples, superfosfato triplo e termofosfatoYoorin, os quais foram misturados ao solo nas quantidades: $0,100,200$ e $300 \mu$ $\mathrm{gP} / \mathrm{g}$ de solo, e incubados durante 60 dias, ao término dos quais fez-se a análise química para caracterizar o solo. Cultivou-se também o arroz cultivar IAC-165 como planta teste por 32 dias. obtendo-se o peso do material seco da parte aérea das plantas e determinou-se os nutrientes nela contidos. 
Analisou-se o fósforo nas amostras de terra pelos métodos de extração: Mehlich-1 $\left(\mathrm{H}_{2} \mathrm{SO}_{4} 0,025 \mathrm{~N}+\mathrm{HCl} 0,05 \mathrm{~N}\right)$, Olsen $\left(\mathrm{NaHCO}_{3}\right.$ a pH 8,5) e Resina trocadora de íons. Determinou-se também os teores de $\mathrm{K}, \mathrm{Ca}, \mathrm{Mg}$, matéria orgânica, $\mathrm{H}+\mathrm{Al}$ e o $\mathrm{pH}$ em $\mathrm{CaCl}_{2}$.

No material seco determinou-se o porcentagem de $\mathrm{P}$ e calculou-se o $\mathrm{P}$ absorvido, que juntamente com o peso da parte aérea foram correlacionados com os teores de fósforo extraídos do solo pelos três métodos.

Os adubos termofosfato, superfosfato simples e superfosfato triplo aumentaram o pH do solo

Os adubos monofosfato de amônio e superfosfato simples na dose $200 \mu \mathrm{gP} / \mathrm{g}$ de solo, proporcionaram maiores pesos de material seco da parte aérea nas plantas de arroz.

Os teores de fósforo absorvidos pelo arroz foram mais elevados nos tratamentos que receberam monofosfato de amônio e superfosfato simples na dose $300 \mu \mathrm{gP} / \mathrm{g}$ de solo.

Os três extratores utilizados para comparar as fontes de fósforo apresentaram pequena diferença na extração de $\mathrm{P}$ e todos correlacionaram-se positivamente com os parámetros avaliados (matéria seca, porcentagem de fósforo e fósforo absorvido pelo arroz), porém o extrator de Olsen correlacionou-se melhor com a resposta do arroz às doses de fósforo utilizadas em cada fonte de adubo fosfatado. 
COMPARISON BETWEEN PHOSPHORUS SOURCES USING TREE SOIL QHEMICAL EXTRACTORS AND RICE PLANTS

\author{
Author: Reynaldo Rocha Beltrán \\ Adviser: Prof. Dr. Ronaldo Ivan Silveira
}

\title{
SUMMARY
}

An experiment was carried out in greenhouse conditions using an acid and low phosphorus soil (Areia Quartzosa, Riberão Claro - Piracicaba S.P.), to of compare phosphate fertilizers, rates and extractors.

The phosphate fertilizers used were: Alvorada rock phosphate, amonion monophosphate, simples superphosphate, triple superphosphate and Yoorin termophosphate. Teh phosphates were mixed with the soil, at rates of 0 , 100,200 and $300 \mu \mathrm{gP} / \mathrm{g}$ of soil and incubated for 60 days.

To evaluate the direct effect of these phosphates a pot experiment was conduced using rice (variety IAC-165) as indicator plant and 32 days later the above-ground parts were cut, dried and weighed.

Phosphorus in soil samples were analised using the following extractors: Mehlich-1 $\left(\mathrm{H}_{2} \mathrm{SO}_{4} 0.025 \mathrm{~N}+\mathrm{HCl} 0.05 \mathrm{~N}\right)$, Olsen $\left(\mathrm{NaHCO}_{3} \mathrm{pH} 8.5\right)$ and ion exchange resina (IR-120 strongh acid and IRA-400 strongh base) and the contentor $\mathrm{k}, \mathrm{Ca}, \mathrm{Mg}$ organic matter and $\mathrm{H}+\mathrm{Al}$ and the index $\mathrm{pH}$ in $\mathrm{CaCl}_{2}$ was determined. 
The dried matter, $\mathrm{P}$ content and $\mathrm{P}$ absorved by the above ground parts was correlated with the $\mathrm{P}$ recovered by the chemical tree methods.

The fertilizers Yoorin termophosphate, simples superphossphate e triple superphosphate possibilited increases of soil $\mathrm{pH}$

The fertilizers MAP and SPS in the rate $200 \mu \mathrm{gP} / \mathrm{g}$ of soil, allow major dry matter in above ground parts of rice plants.

The amount of phosphorus absorved was higher for MAP and SPS in the rate $300 \mu \mathrm{gP} / \mathrm{g}$ of soil.

Litlle diferences bettwen soil chemical P-extractors and a positive correlation with the evaluated parameter was observed. Olsen's extractor showed the best correlation with rice response to rates and sources of $P$. 


\section{INTRODUÇÃO}

O fósforo é um dos três macronutrientes primários das plantas. Embora as quantidades desse nutriente requeridas pelas plantas sejam pequenas, quando comparadas com outros macronutrientes tais como, nitrogênio e potássio por exemplo, ele é utilizado em maiores proporções nas adubações, devido ao fato de uma boa parte do nutriente contido no adubo ser fixado no solo, passando a formas não aproveitáveis pelas plantas, sendo necessário então, a aplicação de grandes quantidades em relação ao que a planta realmente precisa, principalmente em solos ácidos.

Os solos brasileiros tem pouco fósforo disponível às plantas e para contornar essa deficiência, são utilizadas grandes quantidades de adubos fosfatados, sendo que a materia prima principal para fabricação dos mesmos é esgotável, não renovável e insubstituível, o que poderá no futuro provocar uma carência total desta fonte.

A existência de diferentes fontes de fertilizantes fosfatados, com características próprias, quanto à sua solubilidade, tais como: os fosfatos acidulados, os fosfatos térmicos e outros, dificulta a recomendação. Comparandose os fosfatos insolúveis em água, mas solúveis em ácido cítrico a $2 \%$, como os termofosfatos, com os insolúveis em água e em citrato neutro de amônio, como os fosfatos naturais, RAIJ et al (1982) verificaram que os solúveis em água 
são mais eficientes, porém sua maior limitação é o seu custo elevado, pois na sua fabricação, eles requerem processos químicos e térmicos complicados.

"É importante ressaltar, que para as atuais reservas brasileiras conhecidas e supondo uma taxa anual de crescimento da demanda de $5 \%$, sua duração está limitada a aproximadamente 40 anos. Outro fato que deve ser levado em consideração, são as altas perdas de fósforo, que ocorrem desde a etapa de lavra até a assimilação pelas culturas. Essas perdas podem chegar até 98\%" (IPT, 1990)

Os altos investimentos iniciais, com a adubação fosfatada, tem dificultado a exploração efetiva do potencial do solo, pois a correção da deficiência de fósforo se faz normalmente pela aplicação de fosfatos altamente solúveis, como são os superfosfatos simples e triplo e o fosfato de amônio. Esses adubos ao se dissolverem em água, transformam-se em ácido fosfórico $\left(\mathrm{H}_{3} \mathrm{PO}_{4}\right)$ e fosfato ácido de cálcio $\left(\mathrm{CaHPO}_{4}\right)$. Essa solução ácida que se forma no solo, exerce um efeito marcante na disponibilidade de $P$ para as plantas, uma vez que 0 $\mathrm{H}_{3} \mathrm{PO}_{4}$ produzido concorre para a dissolução dos óxidos de $\mathrm{Fe}, \mathrm{Al}$ e $\mathrm{Mn}$, acelerando o processo de fixação de P. Em razão disso, a adubação fosfatada é uma prática indispensável para obtenção de altas produtividades.

A falta de seletividade dos extratores na dissolução dos fosfatos do solo, tem levado a uma variação nos resultados da análise de fósforo "disponível" para as plantas. Considerando que, a quantidade de $\mathrm{P}$ extraida deve ser correlacionada com a produção pela planta. o conhecimento das formas de $\mathbf{P}$, relacionadas com o P "disponivel" obtido pelos extratores, é importante porque permite identificar as formas extraidas preferencialmente em determinado solo e, consequentemente, escolher um método mais adequado para uma área particular. 
$\mathrm{O}$ uso de extratores adequados para os diferentes tipos de solo, tem sido sempre uma grande preocupação dos pesquisadores ao longo dos anos, não se tendo até o momento um extrator que imite a planta, no que se refere a extração do fósforo do solo, nas formas e em quantidades que ela propria o faria.

Há dúvidas, na aplicação de fertilizantes fosfatados, quanto aos processos que levam ao baixo aproveitamento pelas plantas e o uso de um extrator adequado ao nível de laboratório, que permita avaliar com bastante certeza o $\mathrm{P}$ realmente disponível para a planta, considerando ainda que o comportamento tanto dos fertilizantes como dos extratores é diferente para cada solo e para cada cultivo, justifica-se o estudo de alguns fatores que possam interferir nesses processos.

O objetivo deste trabalho foi o de avaliar a disponibilidade do fósforo no solo para as plantas, utilizando-se cinco fontes de adubos fosfatados, três métodos de extração e o arroz como planta teste. 


\section{REVISÃO DE LITERATURA}

\subsection{Fósforo no solo}

Os solos tropicais de uma maneira geral caracterizam-se por ter baixa disponibilidade de fósforo para as plantas, devido ao baixo teor de bases, elevada acidez com alta capacidade de fixação desse nutriente, e atribui-se a este fato, as grandes respostas à adubação fosfatada e à aplicação de elevadas doses de fósforo ao solo (RAIJ, 1991).

Segundo VOLKWEISS \& RAIJ (1977), apesar da baixa disponibilidade de $\mathrm{P}$, o teor total presente no solo é relativamente alto, da ordem de 100 a $200 \mathrm{ppm}$ de $\mathrm{P}$, sendo que a quase totalidade está fazendo parte dos compostos sólidos orgânicos e inorgânicos de baixa solubilidade (P-sólido), restando teores muito baixos, em geral menos de $0,1 \mathrm{ppm}$, dissolvidos na solução (P-solução).

O fósforo na solução do solo (P-solução) está em equilibrio com a da fase sólida (P-sólido), o que pode ser representado, de forma simplificada da seguinte forma:

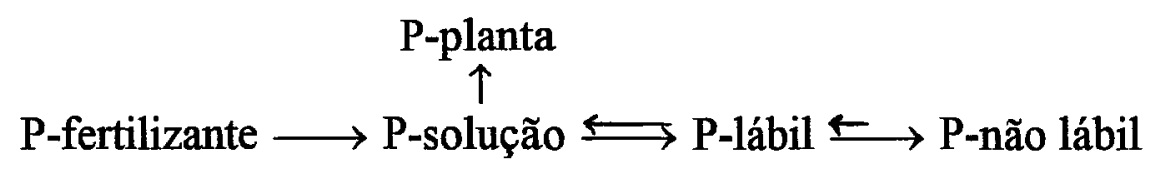


Essa representação descreve bem, o equilibrio do P no sistema soloplanta, mostrando que a disponibilidade para as plantas está diretamente ligada à concentração do elemento na solução do solo. Muito pouco $\mathrm{P}$ está em solução (usualmente menos do que $0,1 \%$ em solos virgens) e a maior parte (frequentemente mais de 90\%) encontra-se como P-não Lábil. Conclui-se então que solos contendo 400 ou $600 \mathrm{~kg} / \mathrm{ha}(200$ a $300 \mathrm{ppm}$ ), de $\mathrm{P}$ total são extremamente deficientes nesse nutriente para as culturas, sendo portanto necessário, para manter-se um nível adequado de $\mathrm{P}$ disponível (P-soluçao), elevar-se o nível das demais formas. Por isso, quando o $\mathrm{P}$ é adicionado vía fertilizantes, grande parte se destina a elevar o nível do P-sólido (P-lábil e P- não lábil) (GOEDERT \& SOUSA, 1984)

COREY (1973) afirma que, os mecanismos através dos quais o $\mathbf{P}$ da solução do solo pode chegar até a zona de absorção das raizes são: interceptação radicular, fluxo de massa e difusão, sendo destes o mais importante o da difusão. MELLO et al. (1980) consideram que, a deficiência de fósforo é um dos principais fatores limitantes da produção agrícola.

Segundo RAIJ (1984), quatro fatores definem a disponibilidade do P na solução do solo: Fator Intensidade, representado pela concentração de $\mathrm{P}$ na solução do solo; Fator Quantidade, representado pelo $\mathrm{P}$ que pode passar para a solução do solo, chamado P-lábil; Fator Capacidade ou também chamado poder tampão de $P$, representado pela condição do solo em poder manter ou restabelecer o P da solução em níveis adequados, através da dissolução do elemento da fase sólida; e Fator Difusão, representado pelas características que permitem aos íons fosfato sair da superficie da fase sólida do solo, e chegar até a superfície das raizes. 
O fósforo que está na solução do solo é considerada como mais disponível para as plantas. O fosfato inorgânico da solução do solo está em equilibrio com os fosfatos da fase sólida, adsorvidos ou combinados com fosfatos de cálcio, alumínio ou ferro. $\mathrm{O}$ fosfato contido na matéria orgânica, pode também incrementar os fosfatos inorgânicos no sistema P-lábil/P-solução, através de processos de mineralização (RAIJ, 1978).

JORGE \& VALADARES (1969) determinaram, as formas em que se encontra o P nativo de dez solos importantes do Estado de São Paulo, e concluiram que, a maior parte do $\mathrm{P}$ encontrado nesses solos estava ligado ao ferro (P-Fe), com excessão do solo Terra Roxa Estruturada que apresentou alto teor de P ligado ao cálcio ( $\mathrm{P}-\mathrm{Ca}$ ), forma considerada aproveitável pelas plantas

MANDAL \& DAS (1970) estudando a transformação de fosfato solúvel aplicado em solos ácidos inundados, verificaram um aumento diferenciado das formas $\mathrm{P}-\mathrm{Al}$ e $\mathrm{P}-\mathrm{Fe}$ nos solos e um decréscimo da forma $\mathrm{P}-\mathrm{Ca}$, atribuindo essas respostas aos conteúdos de $\mathrm{Fe}_{2} \mathrm{O}_{3}$ total e de ferro ativo.

GOEDERT \& LOBATO (1980) afirmaram que, quando um fertilizante fosfatado é adicionado ao solo, ele deve ser dissolvido na solução do solo, e isto significa que, o P fertilizante transforma-se em P-solução.

A maioria das especies cultivadas produz mais quando o $\mathrm{pH}$ do solo está na faixa de $6,0-6,5$. Em um experimento em solução nutritiva utilizando diferentes especies de plantas, MALAVOLTA (1980) verificou que, o crescimento máximo ocorreu em geral quando o $\mathrm{pH}$ da solução foi mantido entre 6,0 e 6,5 , sendo que nos valores extremos $(\mathrm{pH}>9$ e $<3)$ as plantas morreram. $\mathrm{O}$ pH muito baixo prejudicou a absorção de $\mathrm{N}$ e, em escala ainda maior a de $\mathrm{K} \mathrm{e}$, principalmente, a de $\mathrm{P}$ e Ca. A absorção de $\mathrm{P}$ foi impedida quando o $\mathrm{pH}$ era 9,0 . 
O autor afirma ainda, que a disponibilidade máxima do fósforo aconteceu quando o pH da solução do solo estava ao redor de 6,5; é que os valores mais baixos favorecem a formação de fosfatos de $\mathrm{Fe}$ e de $\mathrm{Al}$ de baixa disponibilidade; a elevação do $\mathrm{pH}$, por sua vez conduz à precipitação do $\mathrm{P}$ (solução) como fosfatos de cálcio de menor disponibilidade, ocorrendo a "fixação"do íon $\mathrm{H}_{2} \mathrm{PO}_{4}^{-}$no solo.

\subsection{Fósforo na planta}

O fósforo é um dos macronutrientes primarios que a planta necessita em menores proporções para viver. É considerado essêncial pois, se houver falta a planta não completa o seu ciclo de vida e morre de "fome" de fósforo (MALAVOLTA, 1985).

Segundo FAGERIA (1984) a função que o fósforo desempenha no processo fotossintético é importante, sendo responsável pela acumulação e pelo uso de energia nos vários processos metabólicos. O efeito do fósforo na fisiologia das plantas de arroz é observado pelas seguintes características: formação de células, desenvolvimento das raízes; formação de grãos; melhoria na qualidade dos grãos; processo de maturação e; resistência aos estresses ambientais.

Em geral, a necessidade de adubação fosfatada para o arroz irrigado é menor do que para culturas de sequeiro. Isto deve-se ao aumento da disponibilidade de fósforo do solo, causado pela inundação, e explica porque os solos arrozeiros, em geral com baixo teor de $\mathrm{P}$ disponível, quando mantidos secos, apresentam uma resposta relativamente baixa dessa cultura à adubação fosfatada. Devido à baixa mobilidade do $\mathrm{P}$ no solo e a sua grande translocação 
dentro da planta, este nutriente é importante no inicio do crescimento, obtem-se em geral, os melhores resultados com a aplicação de todo o $\mathrm{P}$ na semeadura. A difusão do $\mathrm{P}$ no solo e o transporte pelo fluxo de massa para as raízes do arroz são favorecidos pela submergência. Nos solos inundados, também as diferenças nas respostas do arroz às diferentes fontes de $\mathrm{P}$ são minimizadas, quando comparadas com as condições de sequeiro. Os fosfatos naturais de boa qualidade, finamente moidos, isolados ou misturados com fosfatos solúveis em água, têm mostrado tão boa eficiência quanto esses últimos, isoladamente (MACHADO, 1985). As condições de oxirredução do solo afetam diretamente as formas inorgânicas do fósforo, favorecendo principalmente, o incremento do $\mathrm{P}-\mathrm{Fe}$ e o decréscimo de $\mathrm{P}$ solúvel, em ambiente redutor (PATRICK Jr. \& MAHAPATRA, 1968).

GOEDERT et al. (1971), estudando as formas de $\mathrm{P}$ e a sua disponibilidade para o arroz irrigado em solo ácido, constataram que os fosfatos de Fe são os mais abundantes entre as formas de $\mathrm{P}$ inorgânico e, que essa fração é a fonte mais importante de $\mathrm{P}$ disponível para a cultura do arroz. Estudando a disponibilidade e as formas de $\mathrm{P}$ para a cultura do arroz irrigado, os autores verificaram uma relação estreita entre produção de arroz e os teores de P na forma "disponível" pelo método Mehlich-1, sendo o $\mathrm{P}$ ligado ao ferro ( $\mathrm{P}-\mathrm{Fe}$ ), a forma mais importante de $P$ para o arroz.

O fósforo é absorvido pelas plantas nas formas de ortofosfato $\mathrm{H}_{2} \mathrm{PO}_{4}^{-}$e $\mathrm{HPO}_{4}^{2-}$, com predominância do primeiro, como consequência não só do efeito do $\mathrm{pH}$ sobre a abundância dessa especie iônica em solução, mas também por um decréscimo marcante de absorção de fósforo em função da elevação do pH da solução (MENGUEL \& KIRKBY, 1987) 
MORAES (1973), estudando a disponibilidade do $P$ para as plantas em alguns solos de México, constatou deficiência de $\mathrm{P}$ em plantas de arroz irrigado, não pela falta do nutriente e sim pela inibição de sua absorção pelas raízes, apontando como causas, o acúmulo de ácidos orgânicos e $\mathrm{H}_{2} \mathrm{~S}$ na camada reduzida do solo, bem como o excesso de Fe-ferroso nos solos ácidos, quando ocorre intensa absorção de $\mathrm{Fe}$ e esse nutriente combina-se com o fósforo ao nível radicular, sendo a translocação deste inibida. PONANMPERUNA (1964) entretanto, afirma que a oxidação do $\mathrm{Fe}$ na rizosfera do arroz, causa a precipitação do $\mathrm{P}$ na forma de $\mathrm{FePO}_{4}$ e que, portanto, o aproveitamento da maior disponibilidade do $\mathrm{P}$ causada pela inundação do solo pode ser, notadamente reduzida e a absorção do $\mathrm{P}$ prejudicada. $\mathrm{O}$ fato do ferro inibir a absorção do $\mathrm{P}$, seja ao nível radicular ou ao nível da rizosfera, torna necessário utilizar-se corretivos, que diminuam sua ação tóxica e, com isso, se consiga um melhor aproveitamento do $\mathrm{P}$ do solo e do $\mathrm{P}$ aplicado ao solo inundado

OLIVEIRA et al.(1984), comparando os efeitos de diferentes doses de $\mathrm{P}_{2} \mathrm{O}_{5}$ sobre a produção de grãos e a altura das plantas de trigo, verificaram aumentos significativos com o aumento das doses de $\mathrm{P}_{2} \mathrm{O}_{5} / \mathrm{ha}$. MORAIS \& GONTIJO (1978), em um experimento com arroz de sequeiro no Triângulo Mineiro, encontraram que as máximas produções foram obtidas com doses de 70 a $80 \mathrm{~kg}$ de $\mathrm{P}_{2} \mathrm{O}_{5} / \mathrm{ha}(35 \mathrm{a} 40 \mu \mathrm{g} / \mathrm{g}$ de solo), associadas a $60 \mathrm{~kg}$ de $\mathrm{N} / \mathrm{ha}$ e $60 \mathrm{~kg}$ de $\mathrm{K}_{2} \mathrm{O} / \mathrm{ha}(30 \mu \mathrm{g} / \mathrm{g})$. Respostas lineares a $120 \mathrm{~kg}$ de $\mathrm{P}_{2} \mathrm{O}_{5} / \mathrm{ha}(60 \mu$ $\mathrm{g} / \mathrm{g}$ ) foram igualmente obtidas por SOUZA et al. (1978) com a cultura do trigo nos mesmos solos.

Todas as culturas removem pequenas quantidades de fósforo do solo. Dos três macronutrientes, ele é o menos absorvido pelas plantas. A 
quantidade removida, está em torno de $5 \mathrm{~kg}$ por hectare por ano e concentra-se principalmente nas flores e frutos, sendo considerado o principal agente de polinização e frutificação das plantas (COELHO \& VERLENGIA, 1973).

\subsection{Comparaçao entre fontes de fósforo}

Diversos pesquisadores vem desenvolvendo pesquisas, com o objetivo de avaliar a eficiência agronômica das diferentes fontes de fósforo existentes no mercado.

Nas jazidas em exploração atualmente, a maior parte da tecnologia de transformação da rocha fosfatada em fertilizantes, obedece ao seguinte processo: jazida $\rightarrow$ fosfato natural concentrado $\rightarrow$ fosfatos solúveis (superfosfatos, fosfato monoamônio e fosfato diamônio) (GOEDERT \& SOUSA, 1984).

Existem basicamente duas rotas de solubilização do fósforo: via úmida e via térmica. A primeira caracteriza-se pelo ataque com ácido sulfúrico ao concentrado fosfático que, dependendo das condições do processo e da reação estequiométrica, pode produzir diretamente superfosfato simples, fosfato parcialmente acidulado ou ainda, produzir ácido fosfórico, que pode então originar o superfosfato triplo (obtido pelo ataque deste ácido ao concentrado). Os fosfatos mono (MAP) e diamônio (DAP) são obitidos pela reação entre o ácido fosfórico e amônia em proporções adequadas (IPT, 1990)

A maior parte do fósforo do solo é proveniente da intemperização da apatita, mineral que contém fósforo e cálcio, além de outros elementos, como o fluor e o cloro. À medida que a apatita desintegra-se e libera o fósforo no solo, 
vários compostos de fósforo são formados, incluindo-se os dois ortofosfatos $\left(\mathrm{H}_{2} \mathrm{PO}_{4}^{-}\right.$e $\left.\mathrm{HPO}_{4}{ }^{2-}\right)$, que são absorvidos pelas plantas. Essas formas geralmente são solúveis e podem ser encontradas dissolvidas, em pequenas quantidades, na solução do solo (LOPES, 1989).

Segundo VIEGAS et al. (1961), o fosfato natural (fosfato de rocha) é obtido pela extração direta de depósitos de minérios de fosfatos que ocorrem na natureza. Os fosfatos naturais dividem-se em dois grupos: os cristalinos e os sedimentares, os primeiros são duros, estáveis e insolúveis em água e os segundos são amorfos, menos estáveis e insolúveis em água (COOKE, 1967). Os fosfatos de origem sedimentar, quando comparados com os fosfatos de origem ígnea, são mais solúveis, devido às substituições que envolvem principalmente o $\mathrm{PO}_{4}^{2-}$ por $\mathrm{CO}_{2}^{-}+\mathrm{F}^{-}$ou $\mathrm{CO}_{2}^{-}+\mathrm{OH}^{-}$, que alteram a estrutura do cristal, diminuindo o seu tamanho e sua estabilidade (LEHR \& McLELLAN, 1972).

Os superfosfatos são os fertilizantes fosfatados mais usados, e desses, os mais importantes são: o superfosfato simples e o triplo (fosfato de cálcio). Este último normalmente é usado como padrão para comparar a eficiência agronômica de fosfatos (GOEDERT \& LOBATO, 1980; BRAGA et al., 1991; GOEDERT et al., 1990).

Em um ensaio em vasos GARGANTINI \& SANTOS (1971), observaram a superioridade do termofosfato na produção de grãos de soja e de materia seca, quando comparado a outras fontes de $\mathrm{P}$.

Vários experimentos de comparação de fontes de $\mathrm{P}$ em quinze estados do oeste norte-americano, mostram que, os superfosfatos simples e triplo, o fosfato diamônio e o ácido fosfórico líquido, foram mais efetivos do que o 
fosfato bicálcico, o fosfato tricálcico e o fosfato natural (Peterson et al., 1953'; citado por SEATZ et al., 1963).

Durante quatro anos, onze fontes de fósforo foram testadas no campo por GOEDERT \& LOBATO (1980), em um latossolo vermelho escuro, sob vegetação de cerrado, usando a sequência de culturas anuais: trigo, soja e arroz. Eles chegaram à conclusão que as fontes são agronômicamente eficientes, na seguinte ordem: 1. Superfosfato triplo, termofosfato magnesiano e fosfato de gafsa; 2. Termofosfato IPT, fosfato de Pirocaua, e fosfatos naturais de Flórida e do Tennesse; 3. Fosfatos naturais de Patos de Minas, Araxá e Abaeté; 4. Fosfato natural de Catalão.

GARGANTINI \& FEITOSA (1974), estudando o comportamento de diversas fontes de fósforo (superfosfato simples e triplo, fosfato diamônio, termofosfato e fosfato natural (apatita de Araxá)), verificaram que no período de 15 a 360 dias após a aplicação dos adubos, os teores de $\mathrm{P}$ extraido pelo $\mathrm{H}_{2} \mathrm{SO}_{4}$ $0,05 \mathrm{~N}$ não mostraram variação com relação ao tempo de contato do solo com os adubos, contudo, comparando os teores de $\mathrm{P}$ extraídos das amostras tratadas pelos diversos adubos, verificaram diferenças significativas.

SALGADO et al. (1984) testaram a resposta da crotalária ã diversos adubos fosfatados, em diferentes tipos de solo e regiões paulistas, considerando-se a produção de massa verde e de sementes. Esses adubos acompanhados de $\mathrm{N}$ e $\mathrm{K}$, foram SPS, SPT, fosfato de Araxá, termofosfato, farinha de ossos degelatinada e Yoorin. Os resultados dos experimentos revelaram que os adubos fosfatados não apresentaram grandes efeitos sobre a produção de material verde e sementes das culturas.

1PETERSON, F.J. et al. Response of rice fertilizer phosphorus and potassium. Bulletin 569. Louisiania. Louisiania State University. 1953. 
Em solos pouco ácidos e pobres em $\mathrm{P}$ disponível, MALAVOLTA et al. (1981), ao comparar a eficiência do fosfato natural parcialmente acidulado com ácido sulfúrico (FAPS), com a do superfosfato simples (SPS) e a do fosfato de Araxá (FA) original, utilizando as culturas de arroz de sequeiro, milho e soja, concluiram que: 1) O efeito do FAPS não diferiu significativamente daquele do SPS, sendo superior ao do FA, em termos de produção; 2) O FAPS comportou-se como fonte de P, Ca e S para as três culturas; 3) Tanto o FAPS como o SPS aumentaram os teores disponíveis de P, Ca e S na planta e no solo; 4) O FAPS teve um comportamento muito mais parecido com o do SPS do que com o FA original.

FERNANDES et al. (1984), trabalhando com diferentes fontes de adubos fosfatados e diferentes níveis de $\mathrm{P}_{2} \mathrm{O}_{5} / \mathrm{ha}$. em dois cultivos sucessivos, utilizando a soja como planta teste, encontraram os seguintes resultados: a) Resposta significativa da cultura à adubação fosfatada; b) $O$ termofosfato magnesiano apresentou comportamento semelhante ao SPT no primeiro cultivo, e foi superior a ele quanto aos efeitos residuais; c) O FA, comparado ao SPT, apresentou eficiência superior a $80 \%$, com ou sem manutenção, possuindo portanto, condições para ser empregado na adubação corretiva em solos com baixa fertilidade.

Em um ensaio em vasos realizado para estudar os efeitos dos fertilizantes fosfatados (SPS, termofosfato e fosforita de Olinda), sobre o $\mathrm{pH}$ e o teor de $\mathrm{Al}^{+3}$ trocável de dois solos (Orthic Haplacrox e Orthic Hapludent) do municipio de Piracicaba-SP, AZEVEDO FILHO et al. (1988) concluiram que, o termofosfato reduziu tanto a acidez ativa $(\mathrm{pH})$, quanto a acidez trocável $\left(\mathrm{Al}^{+3}\right.$ 
trocável) em ambos solos. A fosforita de Olinda e o superfosfato simples reduziram a acidez de troca, mas afetaram muito pouco o $\mathrm{pH}$ dos dois solos.

\subsection{Avaliação da disponibilidade de fósforo}

Existe uma variação muito grande nos métodos de extração de fósforo, em uso nas diferentes regiões do mundo, o que não deixa de ser um reflexo da complexidade do comportamento do elemento, bem como da falta de concordância sobre qual seria o método mais adequado (RAIJ, 1991).

Para a extração de fósforo do solo, as mais variadas soluções (água, soluções tamponadas de ácidos fracos, soluções tamponadas de bases e soluções de sais diversos) tem sido testadas com várias combinações de: concentração, pH, relação solução:solo, tempo de agitação e outros (RAIJ \& QUAGGIO, 1983).

KAMPRATH \& WATSON (1980) classificaram as reações pelas quais o fósforo é extraido do solo, em quatro: 1) Ação solvente de ácidos: as soluções usadas tem $\mathrm{pH}$ geralmente entre 2 e 3 , garantindo a dissolução de fosfatos de cálcio principalmente e em menor intensidade os fosfatos de ferro e alumínio; 2) Substituição de ânions: os fosfatos adsorvidos na superfície do solo podem ser substituidos por outros ânions, tais como sulfato, citrato, lactato ou acetato; 3) Complexação dos cátions combinados com fósforo; o íon mais utilizado é o fluoreto $\left(\mathrm{F}^{-}\right)$, que é muito eficiente na complexação do alumínio, liberando assim o fósforo ligado a esse metal; 4) Hidrólise dos cátions combinados com fósforo: em soluções com $\mathrm{pH}$ mais elevado o $\mathrm{P}$ ligado ao $\mathrm{Fe}$ e Al é liberado por hidrólise dos metais. Os mesmos autores afirmam que, a solução 
de bicarbonato de sódio a $\mathrm{pH} 8,5$, é muito mais eficaz na extração de $\mathrm{P}$ ligado ao $\mathrm{Fe}, \mathrm{Al}$ e $\mathrm{Ca}$ e; extratores de natureza ácida, como Mehlich-1 $(\mathrm{HCl} 0,05 \mathrm{~N}+$ $\mathrm{H}_{2} \mathrm{SO}_{4} 0,025 \mathrm{~N}$ ), mostram uma atividade do íon $\mathrm{H}^{+}$suficiente para solubilizar os fosfatos de cálcio e em menor intensidade o fósforo ligado ao alumínio e ferro. Segundo THOMAS \& PEASLEE (1973), esse extrator é indicado para solos com baixa capacidade de troca de cátions, altamente intemperizados e que contenham pouco ou nenhum fósforo ligado ao cálcio .

Comparando diferentes fontes de fósforo em relação à extração pelos métodos IAC, Bray-1 e Olsen, FERNANDES et al. (1984a) encontraram que, na incorporação do SPT e termofosfato magnesiano (T-Mg), os três extratores foram eficientes em recuperar o fósforo do solo. $\mathrm{Na}$ incorporação do fosfato de Araxá (FA), o método de Olsen foi o mais estável na recuperação do fósforo do solo e em função do tempo de incorporação para as fontes SPT e TMg. Para o FA os métodos Bray-1 e Olsen foram os mais estáveis. A partir da amostragem 960 dias após a incorporação do FA os três métotdos tenderam a se igualar na extração de fósforo. rét todos

Utilizando quatro níveis de $\mathrm{P}$ aplicados em cinco solos do Estado de São Paulo e a cultura do feijão como palanta teste, NEPTUNE \& PEREZ (1987) chegaram às seguintes conclusões: 1) Houve resposta significativa do $P$ adicionado aos solos; 2) A utilização efetiva do P pela leguminosa foi baixa; 3) As melhores correlações do P soluvel com o matérial vegetal seco (MVS) e com o $P$ total presente nele, foram obtidas com os extratores IAC e Mehlich-1 $(r=0,94)$, e 4) Os dois extratores usados para o $P$ orgânico produziram correlações similares com o MVS e o $P$ total presente neste material $(r=0,69)$. Esses mesmos pesquisadores, compararam vários métodos de extração do $\mathrm{P}$ solúvel, $\mathrm{P}$ orgâncio $\mathrm{e}$ 
$\mathrm{P}$ total em cinco solos do Estado de São Paulo e chegaram às seguintes conclusões: Os melhores extratores para o $\mathrm{P}$ solúvel foram IAC $\left(\mathrm{H}_{2} \mathrm{SO}_{4}\right)$ e Mehlich-1 $\left(\mathrm{H}_{2} \mathrm{SO}_{4} 0,025 \mathrm{~N}+\mathrm{HCl} 0,05 \mathrm{~N}\right)$; para remover e medir o $\mathrm{P}$ orgâncio os extratores foram equivalentes ; o método químico de Sommers e Nelson (digestão perclórica) e o de Jackson (fusão com $\mathrm{Na}_{2} \mathrm{CO}_{3}$ e extração com $\mathrm{H}_{2} \mathrm{SO}_{4}$ ) foram os melhores para medir o $\mathrm{P}$ total no solo.

EKPETE (1976), utilizando 13 amostras de solos da Nigéria cultivados com arroz e cinco métodos para avaliar o fósforo disponível (Bray1 e 2, Truog, EDTA e Olsen), encontrou que, o extrator Olsen foi o mais eficiente na predição da disponibilidade de $\mathrm{P}$ nas amostra de solo, tanto inundadas quanto secas.

ROJAS (1976), estudando 47 amostras superficiais de Talca e Nubre, no Chile, encontrou correlações significativas entre a absorção de $\mathrm{P}$ pelas plantas de arroz com o fósforo extraido pelos métodos Mehlich-1 $(r=0,88) e$ Resina $(r=0,80)$, sendo superiores aos métodos Olsen $(r=0,71)$, Bray-2 $(r=0,68)$ e Bray-1 ( $r=0,63)$.

Comparando os extratores Mehlich-1 e Resina na avaliação do $\mathbf{P}$ disponível no solo para gramineas forrageiras e utilizando os resultados de dois experimentos de adubação fosfatada, um realizado em casa de vegetação e outro no campo, CORREAA \& HAAG (1993), através de correlações entre o P extraido com cada extrator e a produção relativa de matérial seco, o $\mathrm{P}$ extraído e o teor de P na planta, concluiram que os dois extratores foram eficientes e similares na avaliação do $\mathrm{P}$ disponível para as plantas, sendo que o método da Resina apresentou maior capacidade de extração do P aplicado. 
GRANDE et al. (1986), em um experimento em casa de vegetação e utilizando oito solos do Estado de Minas Gerais com diferntes teores de fósforo disponivel, dois extratores de $\mathrm{P}$ e $\mathrm{o}$ arroz como planta teste, através da análise de regressão utilizando-se o fósforo absorvido e a produção de matérial seco como parâmetros da disponibilidade de $\mathrm{P}$ no solo, chegaram as seguintes conclusões: 1) O extrator Mehlich-1 mostrou-se pouco eficaz para predizer a disponibilidade de fósforo para o arroz mantido em condições de inundação; 2) A Resina trocadora de íons pareceu ser o extrator mais adequado para avaliar a disponibilidade do P para o arroz irrigado; 3) A eficiência do extrator Mehlich-1 pode ser aprimorada, considerando-se outros fatores, tais como, teores de matéria orgânica ou o P "total".

Um método que se tem mostrado promissor, e atualmente está sendo usado em quase todos os laboratórios de São Paulo, é o da resina trocadora de ânions (RAIJ \& QUAGGIO, 1983). Nesse método, o solo é agitado em água junto com a resina e no processo, o fósforo passa do solo para a resina, de onde é removido posteriormente pela solução extratora.

\subsection{Influência do tempo de incubação na extração de $P$}

A quantidade de P-lábil no solo, proveniente da dissolução do fosfato natural, é diferente daquela proveniente do fosfato solúvel, pois neste último, a quantidade de P-lábil é máxima, logo após seu contato com o solo, decrescendo posteriormente de forma acentuada, enquanto o P-lábil no solo que 
recebeu fosfato de rocha decresce lentamente com o tempo (Larsen, 19712, citado por VOLKWEISS \& RAIJ, 1977).

Diversos experimentos mostram que a dissolução dos fosfatos naturais é mais lenta em relação à dos superfosfatos (SYERS \& MACKAY, 1986; NOVAIS et al.,1980; MOREIRA, 1988).

Um estudo realizado por FEITOSA (1978), em casa de vegetação com dois tipos de solos, utilizando superfosfato triplo, termofosfato, hiperfosfato e fosfato natural (apatita de araxá), mostrou que a incubação dos mesmos por 10, 30 e 120 dias proporcionou pequena variação nos teores de fósforo.

As transformações dos fosfatos solúveis e insolúveis aplicados ao solo, ocorreram dentro dos primeiros 45 dias de incubação, não ocorrendo variações depois desse período até 120 dias (BARBOSA FILHO et al., 1987).

Em oito solos do estado de Paraná LOURENÇO (1971), verificou que a adsorçào de fósforo já era alta com 5 a 10 minutos de reação, atingindo um estado de quase equilibrio após 24 horas. Observou também, que a recuperação de $\mathrm{P}$ pelos extratores químicos é baixa em relação ao total adsorvido. Resultados semelhantes foram alcançados por REZENDE (1974), ao estudar o efeito da fixação de $\mathrm{P}$ em seis solos nordestinos, sendo que dos $2.000 \mathrm{ppm}$ de $\mathrm{P}$ aplicados, $80-90 \%$ já estavam retidos com 24 horas de contato com o solo.

Embora haja uma maior solubilização dos fosfatos naturais com o tempo de contato com o solo, essa reação nem sempre conduz a uma maior disponibilidade de fósforo para as plantas, isto foi verificado por CHIEN (1977), CABALA \& SANTANA (1983) e NOVELINO et al. (1985), que encontraram decrescimos na produção de matérial seco e no fósforo absorvido pelas plantas,

${ }^{2}$ LARSEN, S. Residual phosphate in soils. In. Residual value of applied nutrients. Tech. Bull. 20: 34-41. H.M.S.O., Londres. 1971. 
quanto maior foi o tempo de contato dos fosfatos naturais com o solo. A justificativa de NOVELINO et al. (1985) para o menor aproveitamento do fósforo liberado dos fosfatos pelas plantas, é que os compostos formados no solo com o decorrer do tempo apresentaram menor disponibilidade para as plantas, quando comparados com o superfosfato, que foi considerado como referência. Essa divergência é atribuída pelo autor, ao critério utilizado para avaliar o efeito do tempo de contato sobre a solubilidade e a disponibilidade dos fosfatos pois, além desse outros fatores como, espécie de planta, tipo de solo e, sobretudo, os produtos da reação solo-fertilizante, podem influir na disponibilidade do fósforo. Como as plantas absorvem o fósforo da fração lábil, pode-se prever que quanto mais lenta for a passagem de fósforo da fração lábil para fração não-lábil, maior será a capacidade do solo em suprir fósforo para as plantas. 


\section{MATERIAL E MÉTODOS}

\subsection{Amostragem e preparo do solo}

Um solo ácido e com baixa concentração de fósforo disponível, fatores principais que influencian a imobilização e evidennciam o comportamento do $\mathrm{P}$ adicionado através dos adubos fosfatados foi escolhido, para ser utilizado nas condições naturais, sem qualquer tratamento de correção do $\mathrm{pH}$.

Amostras da camada arável, de 0 a $20 \mathrm{~cm}$ de profundidade, de um solo classificado como Areia Quartzosa, Série Riberão Claro, do municipio de Piracicaba, foram retiradas, secas ao ar, destorroadas e passadas em peneira com malha de $2 \mathrm{~mm}$ de abertura. Subamostras desse solo bem homogeneizadas foram submetidas à análises químicas e o resultado dessas análises são apresentadas na Tabela 1.

\subsection{Localização do experimento}

$O$ experimento foi realizado em casa de vegetação do Departamento de Ciência do Solo, da Escola Superior de Agricultura "Luiz de Queiroz" (ESALQ/USP), em Piracicaba-São Paulo, no período de setembro de 1993 a janeiro de 1994. 
Tabela 1. Resultado das análises químicas do solo antes da aplicação dos adubos fosfatados

\begin{tabular}{|c|c|c|c|c|c|c|c|c|c|c|c|}
\hline \multirow{2}{*}{$\begin{array}{c}\mathrm{pH} \\
\mathrm{CaCl}_{2}\end{array}$} & \multirow{2}{*}{$\begin{array}{c}\text { MO } \\
\%\end{array}$} & \multicolumn{3}{|c|}{$\mathrm{P}\left(\mu \mathrm{g} / \mathrm{cm}^{3}\right)$} & $\mathrm{K}$ & $\mathrm{Ca}$ & $\mathrm{Mg}$ & $\mathrm{H}+\mathrm{Al}$ & SB & $\mathrm{T}$ & \multirow{2}{*}{$\begin{array}{l}\mathrm{V} \\
\% \\
\end{array}$} \\
\hline & & Meh & Ols & Res. & - & - - & $\mathrm{meg} /$ & $0 \mathrm{~cm}^{3}$ & & --- & \\
\hline 3,9 & 1,1 & 4 & 2 & 3 & 0,04 & 0,8 & 0,4 & 3,1 & 1,2 & 4,3 & 29 \\
\hline
\end{tabular}

\subsection{Instalação e condução do experimento}

Os fertilizantes em estudo: fosfato natural (Alvorada), superfosfato simples (SPS), superfosfato triplo (SPT), fosfato monoamônico (MAP) e termofosfato (Yoorin), nas doses 0, 100, 200 e $300 \mu \mathrm{gP} / \mathrm{g}$ de solo, foram bem homogeneizados com $3 \mathrm{~kg}$ de terra e incubados em vasos de cerâmica impermeabilizados internamente com neutrol, por um período de 60 dias, durante o qual a umidade do solo foi mantida próxima da capacidade de campo, através de irrigações periódicas com água destilada, sendo que e as eventuais ervas daninhas que apareceram foram eliminadas manualmente.

Realizou-se a análise dos adubos fosfatados, segundo a metodologia descrita por ALCARDE et al (1990). Os resultados são apresentados na Tabela 2.

Ao término do período de incubação, a terra contida em cada vaso foi novamente seca ao ar, destorroada e passada em peneira com malha de 2 mm de abertura. Após homogeneização, retirou-se amostras para a determinação de $\mathrm{P}$ pelos extratores, assim como $\mathrm{K}, \mathrm{Ca}, \mathrm{Mg}$, determinação de $\mathrm{pH}$, matéria orgânica e $\mathrm{H}+\mathrm{Al}$. $\mathrm{O}$ restante da terra foi divididida em quatro subamostras e 
transferidas para vasos de cerâmica de $500 \mathrm{~g}$, também impermeabilizados internamente com neutrol

Tabela 2. Resultado das análises do Teor de $\mathrm{P}_{2} \mathrm{O}_{5}$ dos adubos fosfatados utilizados e algumas das suas principais características

\begin{tabular}{lcl}
\hline Fertilizante & $\begin{array}{l}\text { Porcentagem } \\
\text { de } \mathrm{P}_{2} \mathrm{O}_{5} \text { total }\end{array}$ & \multicolumn{1}{c}{ Observação* } \\
\hline $\begin{array}{l}\text { Fosfato natural- } \\
\text { Alvorada (FN) }\end{array}$ & $34,70 \%$ & Contém aproximadamente $25 \%$ de Ca \\
$\begin{array}{l}\text { Monofosfato de } \\
\text { amônio (MAP) }\end{array}$ & $52,84 \%$ & Contém aproximadamente $9 \%$ de N \\
$\begin{array}{l}\text { Superfosfato } \\
\text { simples (SPS) }\end{array}$ & $19,81 \%$ & $\begin{array}{l}\text { Contém aproximadamente } 19 \% \text { de Ca } \\
\text { e } 11 \% \text { de S } \\
\begin{array}{l}\text { Superfosfato } \\
\text { triplo (SPT) }\end{array}\end{array}$ Contém aproximadamente $13 \%$ de Ca \\
$\begin{array}{l}\text { Termofosfato- } \\
\text { Yoorin (TER) }\end{array}$ & $18,20 \%$ & $\begin{array}{l}\text { Contém aproximadamente } 19 \% \text { de Ca } \\
\text { e 7\% de Mg e corrige acidez do solo }\end{array}$ \\
\hline
\end{tabular}

*ALCARDE et al. (1990)

O delineamento experimental para a distribuição dos tratamentos foi, o inteiramente casualizado em esquema fatorial: $5 \times 3$ ( 5 fontes $\times 3$ doses) com 4 repetições, perfazendo um total de 60 unidades experimentais.

Utilizou-se como planta teste o arroz (Oriza sativa L.), cultivar IAC-165, de sequeiro e ciclo médio, cedida pelo Laboratório de Sementes do Departamento de Agricultura da ESALQ/USP

A semeadura foi efetuada no dia $12 / 01 / 94$, utilizando 20 sementes por vaso, deixando11 plántulas por ocasião do desbaste que ocorreu 12 dias após a semeadura. A umidade do solo foi calculada para reter $70 \%$ da 
capacidade de campo, repondo-se a perda com irrigações diarias utilizando água destilada.

Efetuou-se duas adubações de cobertura, via água de irrigação com $150 \mathrm{mg}$ de nitrato de amônio, como fonte de $\mathrm{N}(100 \mathrm{ppm}$ de $\mathrm{N})$ e $100 \mathrm{mg}$ de cloreto de potássio, como fonte de K (100 ppm de K) por vaso; aplicou-se também uma solução de $\mathrm{ZnSO}_{4}$ a $5 \%$, como fonte de $\mathrm{Zn}$, pulverizando vía foliar. Realizou-se também um tratamento fitossanitário com o inceticida sistêmico Decis, para evitar a incidência de pragas, utilizando-se a dosagem de $1 \mathrm{ml}$ do produto para $10 \mathrm{ml}$ de água.

A parte aérea das plantas foi colhida com 32 dias de idade, mediante o corte rente à superfície do solo, condicionada em sacos de papel e posta para secar em estufa, com circulação de ar forçada a $60^{\circ} \mathrm{C}$, até peso constante, sendo então pesadas, moidas e guardadas em sacos de papel isento de $\mathbf{P}$ e outros elementos de interesse.

\subsection{Análises químicas da planta e do solo}

O material vegetal foi submetido à digestão nítrico-perclórica, para a determinação de $\mathrm{P}, \mathrm{K}, \mathrm{Ca}, \mathrm{Mg}, \mathrm{Zn}, \mathrm{Fe}, \mathrm{Cu}$ e $\mathrm{Mn}$; à digestão ácida a quente para $\mathrm{N}$; e à incineração a $550^{\circ} \mathrm{C}$ até obtenção de cinza branca para $\mathrm{B}$. Após o preparo dos extratos, a determinação de $\mathrm{P}, \mathrm{S}$ e $\mathrm{B}$, foi feita por colorimetria; N por titulação utilizando o método semi-micro-kjeldhal e o restante dos nutrientes por absorção atómica. As análises foram realizadas conforme as metodologias descritas por MALAVOLTA et al. (1989). 
O fósforo do solo, ao final do período de incubação e após a colheita das plantas foi extraido pelos métodos: Mehlich-1 ( $\mathrm{HCl} 0,05 \mathrm{~N} \mathrm{e}_{2} \mathrm{SO}_{4}$ $0,025 \mathrm{~N})$, Olsen $\left(\mathrm{NaHCO}_{3}\right.$ a $\left.\mathrm{pH} 8,5\right)$ e resina (resinas aniônica e catiônica), segundo as metodologias descritas por NELSON et al. (1953); OLSEN et al. (1954) e RAIJ \& QUAGGIO (1983), respectivamente.

Determinou-se também a matéria orgânica, $\mathrm{pH}$ em $\mathrm{CaCl}_{2} \mathrm{e}$ $\mathrm{H}+\mathrm{Al}$, segundo metodologias descritas por RAIJ \& QUAGGIO (1983).

\subsection{Avaliação dos tratamentos}

Os tratamentos foram avaliados através dos seguintes parâmetros: produção de material seco da parte aérea das plantas, porcentagem de fósforo e fósforo absorvido pela parte aérea das plantas. $O$ fósforo extraído do solo pelos extratores Mehlich, Olsen e Resina foi correlacionado com a resposta do arroz às doses e fontes de fósforo.

A análise estatística dos dados foi feita utilizando-se do programa de computador SANEST. Para a comparação entre as médias foi aplicado o teste de Tukey ao nível de 5\% de probabilidade, efetuou-se também análises de regressão e correlação, selecionando as equações observando os melhores coeficientes. 


\section{RESULTADOS E DISCUSSÃO}

\subsection{Análise do solo antes da semeadura do arroz}

O resultado das análises químicas do solo após a incubação com os fosfatos por um período de 60 dias e antes da semeadura do arroz, são apresentados na Tabela 3. Observa-se que as condicões químicas do solo não são muito favoráveis ao desenvolvimento normal das plantas de arroz, devido a não ter sido realizada a calagem para corrigir a acidez do solo.

Dentre os fosfatos, o termofosfato atingiu o maior índice $\mathrm{pH}$. Essa capacidade de corrigir a acidez do solo, tambem foi observada por MELLO et al (1981) e é devida ao íon silicato presente nos termofosfatos, os superfosfatos aumentaram ligeiramente $\mathrm{o} \mathrm{pH}$ devido à liberação de $\mathrm{OH}^{-}$na solução do solo. Observa-se também que o superfosfato simples e o próprio termofosfato aumentaram a saturação por bases ( $\mathrm{V} \%)$ até níveis considerados ótimos para o desenvolvimento das plantas de arroz $(>50 \%)$.

Em geral os fertilizantes contribuiram para o aumento da V\%, por terem cálcio na sua composição (fosfato natural Alvorada, superfosfato simples e superfosfato triplo) e magnêsio (termofosfato Yoorin), exceto o monofosfato de amônio que não possui na sua constituição nenhum desses nutrientes, considerados como bases. 


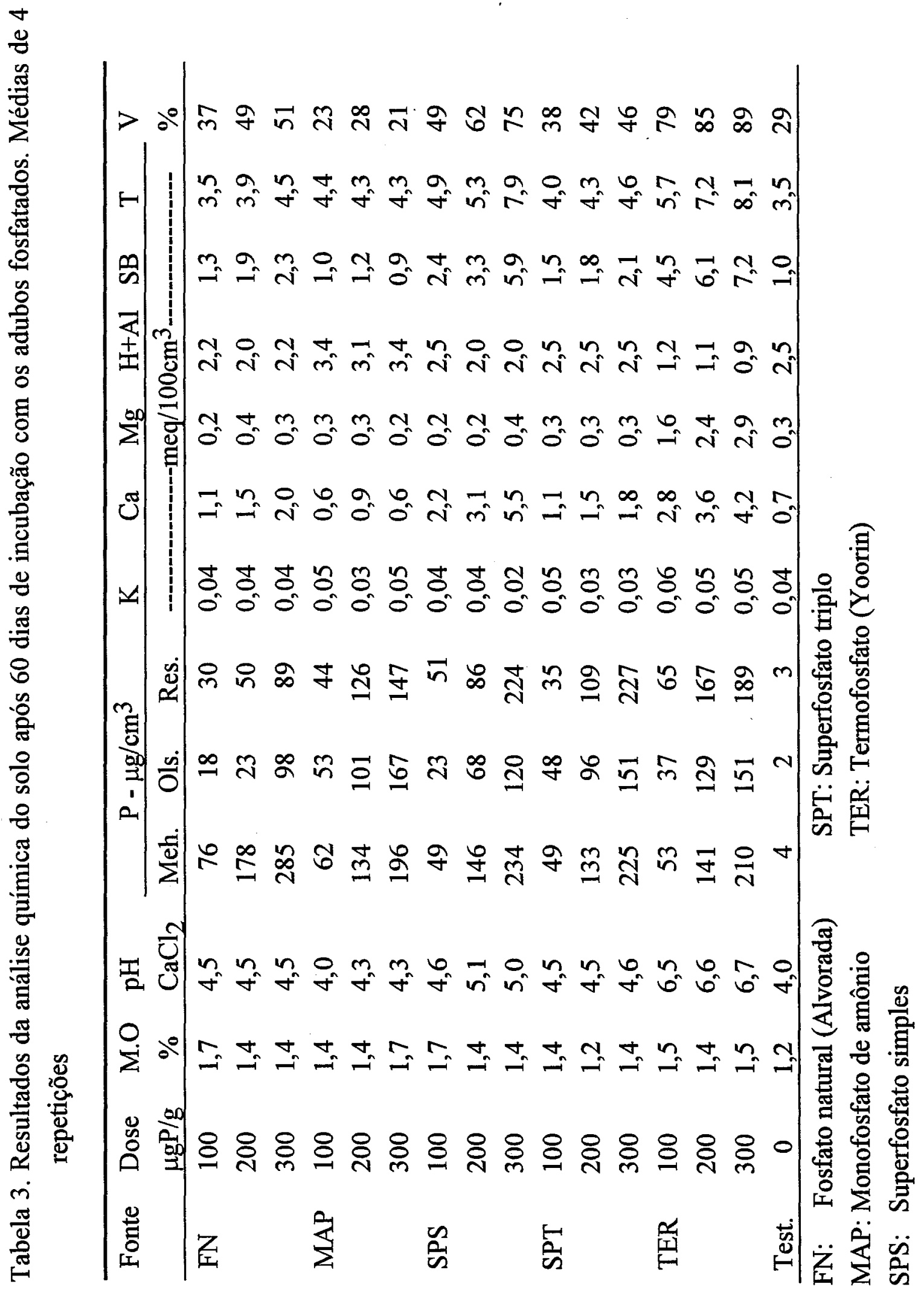


$\mathrm{O} \mathrm{P}$ recuperado pelos três extratores não apresentou grandes diferenças sendo que, em geral o extrator Mehlich foi o que recuperou mais $\mathbf{P}$.

\subsection{Resposta das plantas de arroz às doses e fontes de fósforo}

A análise de variância da produção de material seco da parte aérea das plantas de arroz (tabela 4), mostra os efeitos significativos das doses de fósforo ( $\mu \mathrm{gP} / \mathrm{g}$ de solo) dentro de cada adubo fosfatado aplicado ao solo, sendo que, na dose 0 não houve diferença significativa entre os adubos na produção de material seco, para a dose 100 a maior produção foi obtida com o monofosfato de amônio (MAP), que não diferiu estatisticamente do superfosfato triplo (SPT) e do termofosfato-Yoorin (TER), estes dois últimos não diferiram do superfosfato simples (SPS), e o fosfato natural-Alvorada (FN) foi o que produziu menor quantidade de material seco, porque este fosfato tem baixa capacidade de manter níveis adequados de fósforo na solução.

Resultados semelhantes foram encontrados por GOEDERT \& LOBATO (1980). Tal fato foi explicado pela não dissolução dos minerais fosfatados, pois em nenhum momento eles detectaram aumentos do $\mathrm{P}$ na solução do solo, acreditando que as partículas do fosfato natural tenham sido recobertas por uma camada de óxidos de $\mathrm{Fe}$ e $\mathrm{Al}$, criando-se faces quebradas com desequilibrio de carga, o que resultou em maior dificuldade na liberação de fósforo.

$\mathrm{Na}$ dose 200 a maior produção de material seco foi obtida com o MAP, seguido do SPS, SPT e TER que não diferiram estatisticamente e a menor produção foi obtida com o FN. Na dose 300 a maior produção de material seco 
Tabela 4. Produção de material seco da parte aérea, porcentagem de fósforo no material seco e fósforo absorvido pela parte aérea das plantas de arroz, em função das doses de P para cada fonte de adubo fosfatado. Médias de quatro repetições

\begin{tabular}{|c|c|c|c|c|c|}
\hline & \multirow[t]{2}{*}{ Fontes } & \multicolumn{4}{|c|}{ Doses - $\mu \mathrm{gP} / \mathrm{g}$} \\
\hline & & 0 & 100 & 200 & 300 \\
\hline M.S. & FN & 0,91 с A & $2,87 \mathrm{~b} \quad \mathrm{C}$ & $2,98 \mathrm{~b} \mathrm{C}$ & 3,46 a $\mathrm{A}$ \\
\hline \multirow[t]{4}{*}{ g/vaso } & MAP & $0,94 \mathrm{~d} \mathrm{~A}$ & 3,79 b A & 4,19 a $A$ & $3,05 \mathrm{c} \mathrm{BC}$ \\
\hline & SPS & $0,97 \mathrm{c} \mathrm{A}$ & $3,40 \mathrm{a} \quad \mathrm{B}$ & 3,65 a $B$ & $2,95 \mathrm{~b} \quad \mathrm{C}$ \\
\hline & SPT & 0,99 с A & 3,60 a A B & 3,47 a B & $2,89 \mathrm{~b} \quad \mathrm{C}$ \\
\hline & TER & $1,02 \mathrm{~b} \mathrm{~A}$ & 3,46 a A B & 3,41 a $B$ & 3,33 a A B \\
\hline \multicolumn{3}{|c|}{ C.V. $\%=6,74$} & \multicolumn{3}{|c|}{ DMS 5\%: fontes $=0,1856$, doses $=0,1560$} \\
\hline $\mathbf{P}$ & FN & $0,12 \mathrm{c} \mathrm{A}$ & $0,43 \mathrm{~b} \mathrm{~B}$ & 0,48 a b C & 0,57 a C \\
\hline \multirow[t]{4}{*}{$\% /$ vaso } & MAP & $0,12 \mathrm{dA}$ & $0,31 \mathrm{c} \mathrm{B}$ & $0,78 \mathrm{~b} \mathrm{~B}$ & 1,33 a $\mathrm{B}$ \\
\hline & SPS & $0,12 \mathrm{dA}$ & $0,51 \mathrm{c} \mathrm{A}$ & $0,83 \mathrm{~b} \mathrm{~B}$ & 1,55 a $\mathrm{A}$ \\
\hline & SPT & $0,12 \mathrm{dA}$ & 0,52 c A & $1,03 \mathrm{~b} \mathrm{~A}$ & 1,24 a B \\
\hline & TER & $0,12 \mathrm{~b} \mathrm{~A}$ & 0,56 a $\mathrm{A}$ & 0,54 a C & 0,52 a C \\
\hline \multicolumn{3}{|c|}{ C.V. $\%=10,21$} & \multicolumn{3}{|c|}{ DMS 5\%: fontes $=0,0060$, doses $=0,0050$} \\
\hline $\mathbf{P}$ & FN & $1,10 \mathrm{c} \mathrm{A}$ & $10,87 \mathrm{~b} \mathrm{~B}$ & 14,45 b C & 19,93 a C \\
\hline \multirow[t]{4}{*}{$\mathrm{mg} /$ vaso } & MAP & $1,14 \mathrm{~d} \mathrm{~A}$ & $11,76 \mathrm{c} \mathrm{B}$ & $32,80 \mathrm{~b} \mathrm{~A} \mathrm{~B}$ & 40,39 a B \\
\hline & SPS & $1,17 \mathrm{~d} \mathrm{~A}$ & $17,44 \mathrm{c} \mathrm{A}$ & $30,34 \mathrm{~b} \mathrm{~B}$ & 45,71 a $\mathrm{A}$ \\
\hline & SPT & $1,21 \mathrm{c} \mathrm{A}$ & $16,63 \mathrm{~b} \mathrm{~A}$ & 35,77 a A & 35,89 a B \\
\hline & TER & $1,25 \mathrm{~b} \mathrm{~A}$ & 19,35 a $\mathrm{A}$ & 18,67 a C & 17,45 a C \\
\hline \multicolumn{3}{|c|}{ C.V. $\%=12,49$} & \multicolumn{3}{|c|}{ DMS 5\%: fontes $=0,2334$, doses $=0,4667$} \\
\hline
\end{tabular}

Médias seguidas por letras maiúsculas distintas na vertical ou letras minúsculas distintas na horizontal diferem entre si, pelo teste Tukey ao nível de 5\% de probabilidade. 
foi obtida com o FN, que não diferiu do TER, que por sua vez apresentou-se estatisticamente semelhante ao MAP, e este último não diferiu do SPT e SPS. Isto não indica que o FN seja melhor as outras fontes, acontece que para as outras fontes a dose 200 foi suficiente para produzir o máximo de material seco.

ADAMS \& ODOM (1985), constataram aumentos nos teores de Al em solução, com a aplicação de doses elevadas de adubos fosfatados. COSTA (1980), em ensaios com arroz de sequeiro no estado do Paraná, destacou que as respostas eram maiores para as menores doses de fósforo utilizadas.

A Figura 1 relaciona o fósforo adicionado ao solo como diferentes fontes de adubos fosfatados com a produção de material seco, mostrando efeitos quadráticos altamente significativos, com uma tendência de decréscimo a partir da dose $200 \mu \mathrm{gP} / \mathrm{g}$, para todas as fontes, exceto o $\mathrm{FN}$.

O resultado da análise do teor de fósforo no material seco, em função das doses, dentro de cada adubo fosfatado aplicado ao solo, mostrou efeitos significativos (tabela 4). $\mathrm{Na}$ dose $100 \mathrm{o}$ TER provocou maior porcentagem de fósforo que foi estatisticamente semelhante ao SPT e SPS, os piores teores foram obtidos com o MAP e o FN.

Na dose 200 o SPT foi o adubo que apresentou maior porcentagem de fósforo, seguido do SPS e do MAP que foram semelhantes e do TER e FN que foram os piores. Finalmente na dose 300 o SPS foi o melhor, seguido do SPT e MAP que foram os semelhantes e os piores teores foram do FN e TER que também não diferiram estatisticamente. As testemunhas apresentaram menores porcentagens de $\mathrm{P}$ em relação aos tratamentos com adubos fosfatados.

A Figura 2 relaciona o fósforo adicionado ao solo na forma dos diferentes adubos fosfatados, com a concentração de fósforo no material seco, 


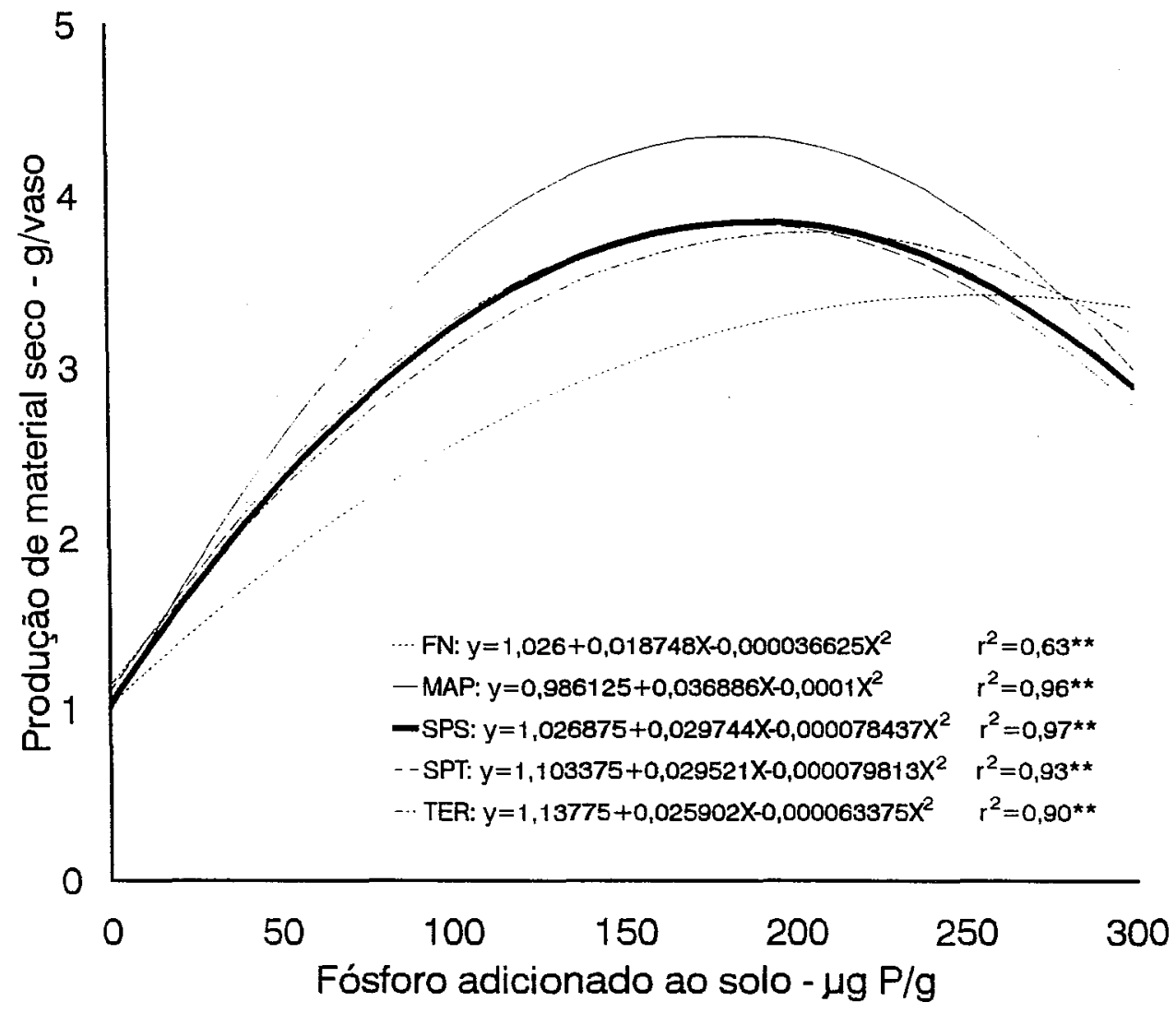

Figura 1. Correlações estabelecidas entre a produção de material seco da parte aérea das plantas de arroz com as doses de $\mathrm{P}$ aplicados ao solo na forma de diferentes adubos fosfatados 


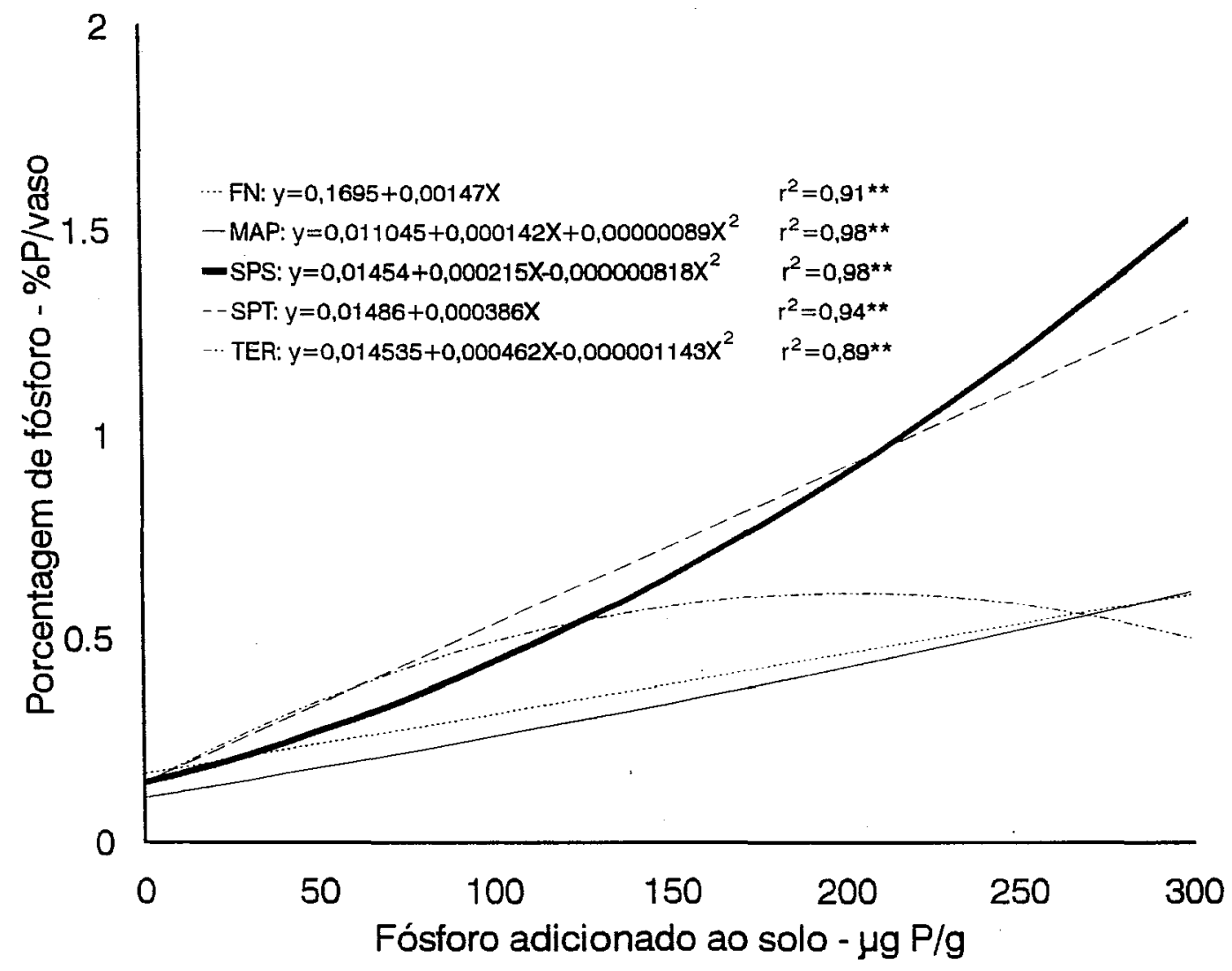

Figura 2. Correlações estabelecidas entre a porcentagem de fósforo no material seco $\mathrm{e}$ as doses de $\mathrm{P}$ adicionadas ao solo na forma de diferentes adubos fosfatados. 
da parte aérea das plantas de arroz, mostrando efeitos quadráticos altamente significativos para os adubos SPS, MAP, e TER e efeitos lineares altamente significativos para os adubos SPT e FN

O resultado da análise de variância do fósforo absorvido pela parte aérea das plantas de arroz em função das doses dentro de cada adubo aplicado ao solo, que é apresentado na Tabela 4, mostra que, o comportamento foi semelhante ao da porcentegem de fósforo no material seco.

A figura 3 correlaciona o fósforo adicionado ao solo na forma dos diferentes adubos fosfatados, com o fósforo absorvido pela parte aérea das plantas de arroz, mostrando efeitos quadráticos altamente significativos dos adubos SPT e TER e efeitos lineares altamente significativos dos adubos SPT, MAP e FN.

A tabela 5 apresenta o resultado da análise das porcentagens dos nutrientes: N, K, Ca, Mg e S, no material seco da parte aérea das plantas de arroz, em função das fontes e doses dos adubos fosfatados aplicados ao solo. Observa-se que para $\mathrm{N}$ na dose $100 \mu \mathrm{gP} / \mathrm{g}$ não houve diferença significativa entre as fontes. A partir da dose 200 o $\mathrm{N}$ apresentou diferença significativa entre as fontes. Os outros nutrientes apresentaram diferenças significativas em todas as doses e fontes. Quando se comparou as doses, todas as fontes apresentaram diferenças significativas, com tendência da testemunha apresentar uma certa superioridade em relação aos tratamentos com adubos para $\mathrm{N}$ e K, devido ao efeito de diluição.

$\mathrm{O}$ resultado da análise de variância das quantidades de $\mathrm{N}, \mathrm{K}, \mathrm{Ca}$, $\mathrm{Mg}$ e S, absorvidas pela parte aérea das plantas de arroz, em função das doses e fontes de adubos fosfatados aplicados ao solo (tabela 6), mostra que as diferenças também existiram. $\mathrm{ON}$ absorvido na dose 100 não apresentou diferença entre os 


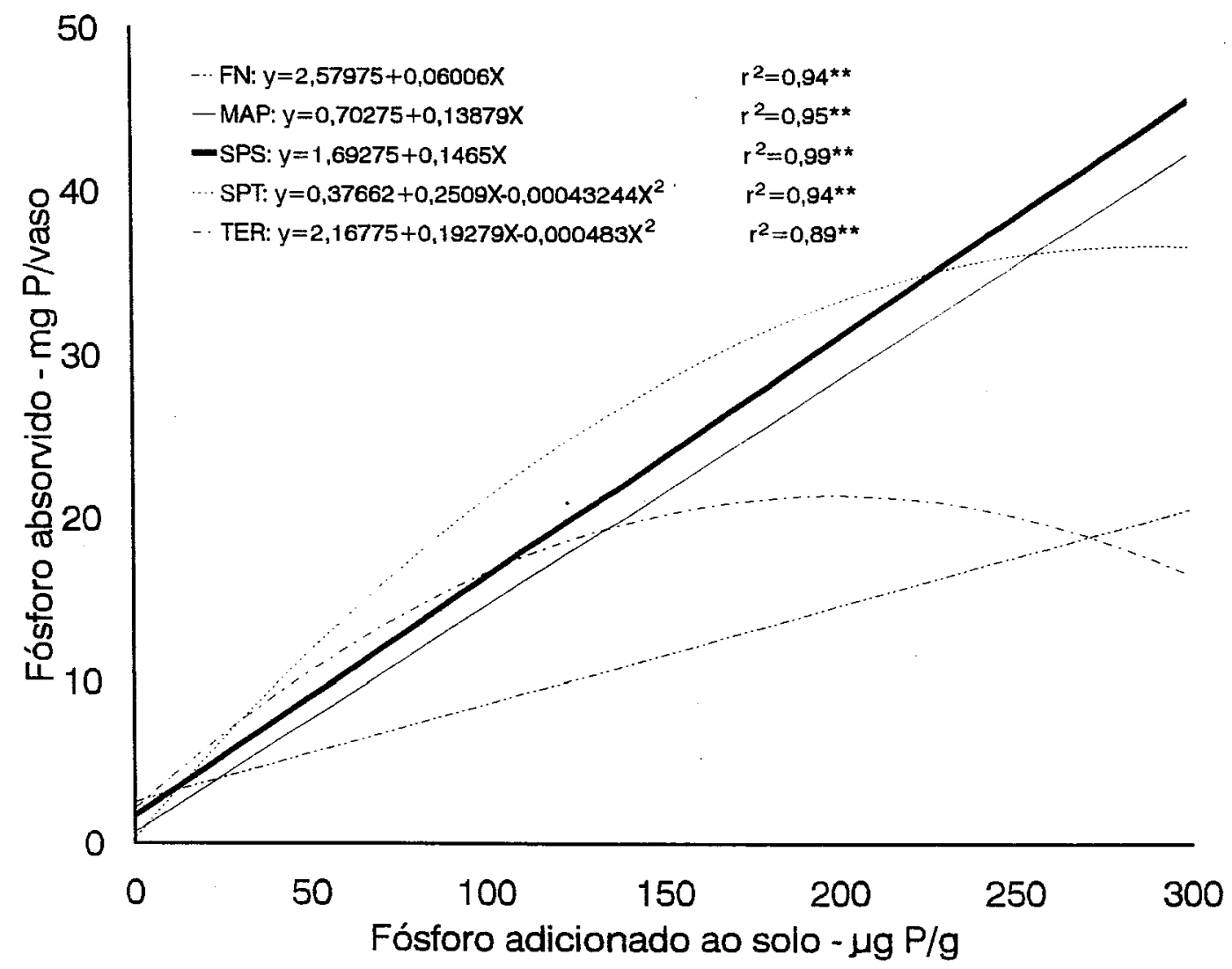

Figura 3. Correlações estabelecidas entre o fósforo absorvido pela parte aérea das plantas de arroz $\mathrm{e}$ as doses de $\mathrm{P}$ aplicados ao solo na forma de diferentes adubos fosfatados 
Tabela 5. Teores de $\mathrm{N}, \mathrm{K}, \mathrm{Ca}, \mathrm{Mg}$ e $\mathrm{S}$, no material seco, em função das doses, para cada fonte de fertilizante fosfatado aplicado ao solo. Médias de quatro repetições

\begin{tabular}{|c|c|c|c|c|c|}
\hline & \multirow[t]{2}{*}{ Fontes } & \multicolumn{4}{|c|}{ Doses - $\mu \mathrm{P} / \mathrm{g}$ de solo } \\
\hline & & 0 & 100 & 200 & 300 \\
\hline \multirow{5}{*}{$\mathrm{N}$} & $\mathrm{FN}$ & $2.05 \mathrm{a} A$ & $1.71 \mathrm{ab} A$ & $167 \mathrm{bB}$ & $150 \mathrm{~h} \mathrm{C}$ \\
\hline & MAP & $2,05 \mathrm{~b} \mathrm{~A}$ & $1,51 \mathrm{c} \mathrm{A}$ & 1,81 b c A B & $2,62 \mathrm{a} \mathrm{A}$ \\
\hline & SPS & $2,05 \mathrm{a} \mathrm{b} \mathrm{A}$ & 1,77 b c A & 2,12 a $A$ & 1,65 c C \\
\hline & SPT & 2,06 a A & 1,55 b A & 1,76 a b A B & 2,07 a $A$ \\
\hline & $\mathrm{TF}$ & 2,06 a $\mathrm{A}$ & $1,53 \mathrm{~b} \mathrm{~A}$ & 1,66 b B & $1,62 \mathrm{~b} \mathrm{C}$ \\
\hline \multicolumn{3}{|c|}{ C.V. $\%=10,16$} & \multicolumn{3}{|c|}{ D.M.S.: fontes $=0,1863$, doses $=0,1566$} \\
\hline \multirow[t]{5}{*}{$\bar{K}$} & FN & 2,06 a $A$ & $1,09 \mathrm{~b} \mathrm{~A}$ & $1,05 \mathrm{~b} \mathrm{~A}$ & $0,97 \mathrm{~b} \mathrm{~B}$ \\
\hline & MAP & 1,92 a A & $0,82 \mathrm{c} \mathrm{B}$ & $0,80 \mathrm{c} \mathrm{B}$ & 1,14 b A B \\
\hline & SPS & 2,05 a $\mathrm{A}$ & 0,95 с A B & 0,88 с A B & 1,16 b A B \\
\hline & SPT & 2,05 a A & 0,89 с B & 0,96 с A B & $1,29 \mathrm{~b} \mathrm{~A}$ \\
\hline & TF & 2,05 a A & $0,90 \mathrm{~b} \mathrm{~B}$ & $0,90 \mathrm{~b}$ A B & 1,03 b B \\
\hline \multicolumn{3}{|c|}{ C.V. $\%=7,48$} & \multicolumn{3}{|c|}{ D.M.S.: fontes $=0,0929$, doses $=0,0781$} \\
\hline \multirow[t]{5}{*}{$\mathrm{Ca}$} & $\mathrm{FN}$ & $0,34 \mathrm{c} \mathrm{A}$ & 0,45 b B C & 0,47 a b B & 0,54 a C \\
\hline & MAP & 0,34 a $\mathrm{A}$ & 0,38 a C D & $0,26 \mathrm{~b} \mathrm{C}$ & 0,34 a b D \\
\hline & SPS & $0,34 \mathrm{~b} \mathrm{~A}$ & 0,56 a $\mathrm{A}$ & 0,61 a $A$ & 0,63 a $B$ \\
\hline & SPT & $0,35 \mathrm{~d} \mathrm{~A}$ & 0,49 с A B & 0,57 b A & 0,74 a $A$ \\
\hline & $\mathrm{TF}$ & 0,35 a $\mathrm{A}$ & 0,37 a D & 0,34 a C & 0,37 a D \\
\hline \multicolumn{3}{|c|}{ C.V. $\%=9,58$} & \multicolumn{3}{|c|}{ D.M.S.: fontes $=0,0422$, doses $=0,0355$} \\
\hline \multirow[t]{5}{*}{$\overline{\mathrm{Mg}}$} & FN & 0,16 a b A & 0,19 a B & 0,17 a b B C & $0,15 \mathrm{~b} \mathrm{C}$ \\
\hline & MAP & 0,16 a $A$ & $0,12 \mathrm{~b} \mathrm{C}$ & 0,14 a b D & 0,16 a C \\
\hline & SPS & 0,16 a b A & 0,12 c C & 0,14 b c C D & 0,18 a $C$ \\
\hline & SPT & $0,16 \mathrm{c} \mathrm{A}$ & $0,22 \mathrm{~b}$ B & $0,20 \mathrm{~b}$ B & 0,28 a $B$ \\
\hline & TF & $0,16 \mathrm{cA}$ & 0,40 a $A$ & $0,36 \mathrm{~b} \mathrm{~A}$ & 0,38 a b A \\
\hline \multicolumn{3}{|c|}{ C.V. $\%=9,17$} & \multicolumn{3}{|c|}{ D.M.S.: fontes $=0,0183$, doses $=0,0367$} \\
\hline \multirow[t]{5}{*}{$\mathrm{S}$} & FN & 0,13 a $\mathrm{A}$ & 0,07 b B & $0,06 \mathrm{~b} D$ & 0,07 b D \\
\hline & MAP & 0,13 a b A & 0,08 c B & 0,10 b c B C & 0,15 a $C$ \\
\hline & SPS & $0,13 \mathrm{~d} A$ & 0,19 с $A$ & 0,25 b A & 0,29 a $A$ \\
\hline & SPT & 0,15 b A & 0,09 с B & 0,11 c B & 0,20 a B \\
\hline & $\mathrm{TF}$ & 0,13 a $A$ & \multirow{2}{*}{\multicolumn{3}{|c|}{ D.M.S.: fontes $=0,0198$, doses $=0,0167$}} \\
\hline \multicolumn{3}{|c|}{ C.V. $\%=15,27$} & & & \\
\hline
\end{tabular}

Médias seguidas por letras maiúsculas distintas na vertical ou letras minúsculas distintas na horizontal, diferem entre si pelo teste Tukey, ao nível de $5 \%$ de probabilidade.. 
Tabela 6. Quantidades de: $\mathrm{N}, \mathrm{K}, \mathrm{Ca}, \mathrm{Mg}$ e $\mathrm{S}$ absorvidas pela parte aérea das plantas de arroz em função das doses, para cada fertilizante fosfatado aplicado ao solo. Médias de quatro repetições

\begin{tabular}{|c|c|c|c|c|c|}
\hline \multirow{2}{*}{\multicolumn{2}{|c|}{ Fontes }} & \multicolumn{4}{|c|}{ Doses $-\mu \mathrm{P} / \mathrm{g}$ de solo } \\
\hline & & 0 & 100 & 200 & 300 \\
\hline \multirow[t]{5}{*}{$\mathrm{N}$} & $\mathrm{FN}$ & 18,84 b A & 49,04 a $A$ & 49,70 a $B$ & $52.08 \mathrm{a} B$ \\
\hline & MAP & 19,39 c A & $57,34 \mathrm{~b} \mathrm{~A}$ & 75,95 a A & 80,98 a $\mathrm{A}$ \\
\hline & SPS & 19,99 с A & 60,13 b A & $77,50 \mathrm{~b}$ A & 48,87 a $B$ \\
\hline & SPT & $20,50 \mathrm{~b} \mathrm{~A}$ & 55,71 a $\mathrm{A}$ & 61,24 a B & 59,68 a B \\
\hline & TF & 21,06 b A & 53,06 a $\mathrm{A}$ & 56,72 a $B$ & 54,14 a B \\
\hline \multicolumn{3}{|c|}{ C.V. $\%=13,79$} & \multicolumn{3}{|c|}{ D.M.S.: fontes $=6,8035$, doses $=5,7183$} \\
\hline \multirow[t]{5}{*}{$\mathrm{K}$} & FN & 18,78 a $\mathrm{A}$ & 31,17 a $\mathrm{A}$ & 31,22 a $\mathrm{A}$ & 33,79 a $\mathrm{A}$ \\
\hline & MAP & 18,16 a A & 31,24 a $A$ & 33,60 a $\mathrm{A}$ & 34,58 a $\mathrm{A}$ \\
\hline & SPS & 19,88 a $\mathrm{A}$ & 32,42 a $\mathrm{A}$ & 32,00 a $\mathrm{A}$ & 34,20 a $\mathrm{A}$ \\
\hline & SPT & 20,43 a $\mathrm{A}$ & 32,21 a $\mathrm{A}$ & 33,46 a $\mathrm{A}$ & 37,31 a $\mathrm{A}$ \\
\hline & TF & 20,98 a $\mathrm{A}$ & 31,09 a $\mathrm{A}$ & 30,71 a $\mathrm{A}$ & 34,44 a $\mathrm{A}$ \\
\hline \multicolumn{3}{|c|}{ C.V. $\%=10,05$} & \multicolumn{3}{|c|}{ D.M.S.: fontes $=2,9581$, doses $=2,4862$} \\
\hline \multirow[t]{5}{*}{$\mathrm{Ca}$} & FN & 3,15 c A & $12,97 \mathrm{~b} \mathrm{~B}$ & 14,07 b B & 18,89 a $A$ B \\
\hline & MAP & 3,25 c A & 14,61 a B & $11,03 \mathrm{~b} \mathrm{C}$ & 10,32 b C \\
\hline & SPS & $3,35 \mathrm{c} \mathrm{A}$ & 19,06 b A & $22,21 \mathrm{c} \mathrm{A}$ & 18,48 b B \\
\hline & SPT & 3,46 с A & 17,68 b A & 20,00 a b A & 21,30 a $\mathrm{A}$ \\
\hline & $\mathrm{TF}$ & 3,57 b A & 12,70 a $B$ & 11,81 a C & 12,25 a C \\
\hline \multicolumn{3}{|c|}{ C.V $\%=10,25$} & \multicolumn{3}{|c|}{ D.M.S.: fontes $=1,2960$, doses $=1,0892$} \\
\hline \multirow[t]{5}{*}{$\mathrm{Mg}$} & FN & $1,44 \mathrm{~b} \mathrm{~A}$ & 5,38 a C & 5,22 a C & 5,28 a C \\
\hline & MAP & $1,49 \mathrm{c} \mathrm{A}$ & $4,55 \mathrm{~b} \mathrm{C}$ & 5,76 a BC & $4,74 \mathrm{a} \mathrm{b} \mathrm{C}$ \\
\hline & SPS & $1,54 \mathrm{~b} \mathrm{~A}$ & 4,25 a $C$ & 5,10 a C & 5,28 a $C$ \\
\hline & SPT & $1,60 \mathrm{~b} \mathrm{~A}$ & 7,92 a $B$ & 6,87 a B & 8,07 a B \\
\hline & TF & $1,65 \mathrm{c} \mathrm{A}$ & 14,02 a $\mathrm{A}$ & $12,41 \mathrm{~b} \mathrm{~A}$ & $12,69 \mathrm{~b} \mathrm{~A}$ \\
\hline \multicolumn{3}{|c|}{ C.V $\%=11,16$} & \multicolumn{3}{|c|}{ D.M.S.: fontes $=0,6399$, doses $=0,5379$} \\
\hline \multirow[t]{5}{*}{$\mathbf{S}$} & FN & $1,20 \mathrm{~b} \mathrm{~A}$ & 2,06 a b C & 1,83 a b C & 2,55 a C \\
\hline & MAP & 1,23 с A & $3,28 \mathrm{~b} \mathrm{~B}$ & 4,52 a $B$ & 4,63 a $B$ \\
\hline & SPS & 1,27 c A & $6,65 \mathrm{~b} \mathrm{~A}$ & 9,22 a $\mathrm{A}$ & 8,57 a $\mathrm{A}$ \\
\hline & SPT & $1,30 \subset \mathrm{A}$ & 3,32 b B & 3,92 b B & 5,76 a B \\
\hline & TF & $1,33 \mathrm{~b} \mathrm{~A}$ & 2,91 a B C & 2,36 a b C & $2,78 \mathrm{aC}$ \\
\hline \multicolumn{3}{|c|}{ C.V. $\%=16,98$} & \multicolumn{3}{|c|}{ D.M.S.: fontes $=0,5977$, doses $=0,5023$} \\
\hline
\end{tabular}

Médias seguidas por letras maiúsculas distintas na vertical ou letras minúsculas distintas na horizontal, diferem entre si pelo teste Tukey ao nível de $5 \%$ de probabilidade. 
adubos, já na dose 200, começou a aparecer o efeito do MAP que tem $\mathrm{N}$ na sua composição (tabela 2), mas as diferenças em relação ao SPT ainda não foram significativas. $\mathrm{Na}$ dose 300 , o MAP aicançou o máximo de $\mathrm{N}$ absorvido e esta diferença deve-se ao fato de ter sido aplicada uma única dose de $\mathrm{N}$ na forma de nitrato de amônio para todos os tratamentos. Quanto ao $\mathrm{K}$ não se observou diferença significativa em nehuma das doses para todos os adubos aplicados, devido aos adubos não passuirem na sua composição este nutriente e ter sido aplicada uma única dose de $\mathrm{K}$ na forma de $\mathrm{KCl}$ para todos os tratamentos.

$\mathrm{O}$ comportaemento do $\mathrm{Ca}, \mathrm{Mg}$ e $\mathrm{S}$ foram semelhantes ao do $\mathrm{N}$, sendo as diferenças devidas ao fato dos adubos conterem esses nutrientes na sua composição, apresentando maior absorção do nutriente nos adubos que os contem.

As Tabelas 7 e 8 apresentam os resultados da análise de variância da produção de material seco, da porcentagem de $\mathrm{P}, \mathrm{N}, \mathrm{K}, \mathrm{Ca}, \mathrm{Mg}$ e S no material seco, e das quantidades desses nutrientes absorvidos pela parte aérea das plantas de arroz, em função dos tratamentos (fontes e doses). Pode-se observar, que o teste $\mathrm{F}$ foi altamente significativo para todas os parâmetros, mostrando efeitos significativos dos tratamentos. Observa-se também, baixos coeficientes de variação, evidenciando que os dados obtidos não tiveram grandes diferenças dentro das repetições.

\subsection{Fósforo recuperado pelos extratores Mehlich-1, Olsen e Resina}

Os teores de fósforo obtidos com os extratores, para cada dose do nutriente adicionada ao solo, apresentaram comportamento bastante diferenciado 
Tabela 7. Análise de variância da produção de material seco (MS) da parte aérea das plantas de arroz e porcentagem de $\mathrm{P}, \mathrm{N}, \mathrm{K}, \mathrm{Ca}, \mathrm{Mg}$ e $\mathrm{S}$ na $\mathrm{MS}$, em função das doses de adubos fosfatados aplicados ao solo

\begin{tabular}{|c|c|c|c|c|c|}
\hline & Causas da variação & G.L. & S.Q. & Q.M. & Valor F \\
\hline M.S. & Fonte & 4 & 1,5939420 & 0,3984855 & $11,446^{* *}$ \\
\hline \multirow[t]{4}{*}{ g/vaso } & Dose & 3 & 88,2760359 & 29,4253453 & $845,276 * *$ \\
\hline & Fonte $\mathrm{x}$ Dose & 12 & 4,4312019 & 0,3692668 & $10,608 * *$ \\
\hline & Residuo & 60 & 2,0886912 & 0,0348115 & \\
\hline & Total & 79 & 96,3898709 & & \\
\hline \multicolumn{2}{|c|}{ Média geral $=2,768000$} & \multicolumn{3}{|c|}{ Coeficiente de variação $=6,741 \%$} & \\
\hline $\mathbf{P}$ & Fonte & 4 & 1,7718696 & 0,4429674 & $122,451^{* *}$ \\
\hline \multirow[t]{4}{*}{$\%$} & Dose & 3 & 9,2641993 & 3,0880664 & $853,644 * *$ \\
\hline & Fonte $\mathrm{x}$ Dose & 12 & 2,6499202 & 0,2208267 & $61,044 * *$ \\
\hline & Residuo & 60 & 0,2170507 & 0,0036175 & \\
\hline & Total & 79 & 13,9030397 & & \\
\hline \multicolumn{2}{|c|}{ Média geral $=0,589000$} & \multicolumn{3}{|c|}{ Coeficiente de variação $=10,212 \%$} & \\
\hline $\mathbf{N}$ & Fonte & 4 & 0,8923693 & 0,2230923 & $6,3362^{* *}$ \\
\hline \multirow[t]{4}{*}{$\%$} & Dose & 3 & 2,0300132 & 0,6766711 & $19,2970 * *$ \\
\hline & Fonte $\mathrm{x}$ Dose & 12 & 3,2947100 & 0,2745592 & $7,8298 * *$ \\
\hline & Residuo & 60 & 2,1039660 & 0,0350661 & \\
\hline & Total & 79 & 8,3210585 & & \\
\hline \multicolumn{2}{|c|}{ Média geral $=1,842125$} & \multicolumn{3}{|c|}{ Coeficiente de variação $=10,165 \%$} & \\
\hline$\overline{\mathrm{K}}$ & Fonte & 4 & 0,1826299 & 0,0456575 & $5,2310^{* *}$ \\
\hline \multirow[t]{4}{*}{$\%$} & Dose & 3 & 16,5655846 & 5,5218615 & $632,6080 * *$ \\
\hline & Fonte $\mathrm{x}$ Dose & 12 & 0,4151401 & 0,0345950 & $3,9630 * *$ \\
\hline & Residuo & 60 & 0,5237239 & 0,0087287 & \\
\hline & Total & 79 & 17,6870785 & & \\
\hline \multicolumn{2}{|c|}{ Média geral $=1,249125$} & \multicolumn{3}{|c|}{ Coeficiente de variação $=7,479 \%$} & \\
\hline $\mathrm{Ca}$ & Fonte & 4 & 0,5979948 & 0,1494987 & $82,9779 * *$ \\
\hline \multirow[t]{4}{*}{$\%$} & Dose & 3 & 0,3287049 & 0,1095683 & $60,8149 * *$ \\
\hline & Fonte $\mathrm{x}$ Dose & 12 & 0,3162751 & 0,0263563 & $14,6288 * *$ \\
\hline & Residuo & 60 & 0,1081002 & 0,0018017 & \\
\hline & Total & 79 & 1,3510749 & & \\
\hline \multicolumn{2}{|c|}{ Média geral $=0,443250$} & \multicolumn{3}{|c|}{ Coeficiente de variação $=9,756 \%$} & \\
\hline $\mathbf{M g}$ & Fonte & 4 & 0,3706950 & 0,0926737 & $272,5680^{* *}$ \\
\hline \multirow[t]{4}{*}{$\%$} & Dose & 3 & 0,0541000 & 0,0180333 & $53,0390 * *$ \\
\hline & Fonte $\mathrm{x}$ Dose & 12 & 0,1412450 & 0,0117704 & $34,6187 * *$ \\
\hline & Residuo & 60 & 0,0204001 & 0,0003400 & \\
\hline & Total & 79 & 0,5864400 & & \\
\hline \multicolumn{2}{|c|}{ Média geral $=0,201000$} & \multicolumn{3}{|c|}{ Coeficiente de variação $=9,174 \%$} & \\
\hline $\mathbf{S}$ & Fonte & 4 & 0,1829779 & 0,0457445 & $114,9390 * *$ \\
\hline \multirow[t]{4}{*}{$\%$} & Dose & 3 & 0,0313764 & 0,0104588 & $26,2792 * *$ \\
\hline & Fonte $x$ Dose & 12 & 0,0842094 & 0,0070174 & $17,6323 * *$ \\
\hline & Residuo & 60 & 0,0238793 & 0,0003980 & \\
\hline & Total & 79 & 0,3224430 & & \\
\hline \multicolumn{2}{|c|}{ Média geral $=0,130612$} & \multicolumn{3}{|c|}{ Coeficiente de variação $=15,274 \%$} & \\
\hline
\end{tabular}


Tabela 8. Análise de variância das quantidades de $\mathrm{P}, \mathrm{N}, \mathrm{K}, \mathrm{Ca}, \mathrm{Mg}$ e $\mathrm{S}$ absorvidos pela parte aérea das plantas de arroz, em função das doses, para cada fertlizante fosfatado aplicado ao solo

\begin{tabular}{|c|c|c|c|c|c|}
\hline & Causas da variação & G.L. & S.Q. & Q.M. & Valor F \\
\hline $\mathbf{P}$ & Fonte & 4 & 1920,55598 & 480,13899 & $90,2002 * *$ \\
\hline \multirow[t]{5}{*}{ mg } & Dose & 3 & 11001,87833 & 3667,29278 & $688,9474 * *$ \\
\hline & Fonte $\mathrm{x}$ Dose & 12 & 2241,27115 & 186,77259 & \\
\hline & & & & & $35,0876 * *$ \\
\hline & Residuo & 60 & 319,38225 & 5,32304 & \\
\hline & Total & 79 & 154,86746 & & \\
\hline \multicolumn{2}{|c|}{ Média geral $=18,792250$} & \multicolumn{3}{|c|}{ Coeficiente de variação $=12,277 \%$} & \\
\hline $\mathrm{N}$ & Fonte & 4 & 2316,8222191 & 579,2055548 & $12,3882 * *$ \\
\hline \multirow[t]{4}{*}{$\mathrm{mg}$} & Dose & 3 & 24268,1377572 & 8089,3792540 & $173,018^{* *}$ \\
\hline & Fonte $\times$ Dose & 12 & 2970,6164167 & 247,5513681 & $5,2947 * *$ \\
\hline & Residuo & 60 & 2805,2707577 & 46,7545126 & \\
\hline & Total & 79 & 32360,8471508 & & \\
\hline \multicolumn{2}{|c|}{ Média geral = 49,596401 } & \multicolumn{3}{|c|}{ Coeficiente de variação $=13,787 \%$} & \\
\hline $\bar{K}$ & Fonte & 4 & 38,9461789 & 9,7365447 & $1,1016^{* *}$ \\
\hline \multirow[t]{4}{*}{ mg } & Dose & 3 & 2753,3631631 & 917,7877210 & $103,849^{* *}$ \\
\hline & Fonte $\mathrm{x}$ Dose & 12 & 47,4134034 & 3,9511169 & $0,4470 * *$ \\
\hline & Residuo & 60 & 530,3044162 & 8,8384069 & \\
\hline & Total & 79 & 3370,0271616 & & \\
\hline \multicolumn{2}{|c|}{ Média geral $=29.585163$} & \multicolumn{3}{|c|}{ Coeficiente de variação $=10,049 \%$} & \\
\hline $\mathrm{Ca}$ & Fonte & 4 & 534,0923407 & 133,5230852 & $78,7066^{* *}$ \\
\hline \multirow[t]{4}{*}{ mg } & Dose & 3 & 2338,9097129 & 779,6365710 & $459,565^{* *}$ \\
\hline & Fonte $\times$ Dose & 12 & 352,3203223 & 29,3600269 & $17,3066 * *$ \\
\hline & Residuo & 60 & 101,7879074 & 1,6964651 & \\
\hline & Total & 79 & 3327,1102833 & & \\
\hline \multicolumn{2}{|c|}{ Média geral $=12,709038$} & \multicolumn{3}{|c|}{ Coeficiente de variação $=10,248 \%$} & \\
\hline $\mathrm{Mg}$ & Fonte & 4 & 438,1744691 & 109,5436173 & $264,803 * *$ \\
\hline \multirow[t]{4}{*}{ mg } & Dose & 3 & 474,6753147 & 158,2251049 & $382,482^{* *}$ \\
\hline & Fonte $\mathrm{x}$ Dose & 12 & 153,4875076 & 12,7906256 & $30,9192 * *$ \\
\hline & Residuo & 60 & 24,8207707 & 0,4136795 & \\
\hline & Total & 79 & 1091,1580621 & & \\
\hline \multicolumn{2}{|c|}{ Média geral $=5,763913$} & \multicolumn{3}{|c|}{ Coeficiente de variação $=11,159 \%$} & \\
\hline $\mathrm{S}$ & Fonte & 4 & 198,7307343 & 49,6826386 & $137,692^{* *}$ \\
\hline \multirow[t]{4}{*}{ mg } & Dose & 3 & 152,3468799 & 50,7822933 & $140,739 * *$ \\
\hline & Fonte $\times$ Dose & 12 & 84,4613919 & 7,0384493 & $19,5066 * *$ \\
\hline & Residuo & 60 & 21,6494761 & 0,3608216 & \\
\hline & Total & 79 & 457,1884822 & & \\
\hline Méd & $=3,536400$ & $\mathrm{Co}$ & iente de variação $=$ & $986 \%$ & \\
\hline
\end{tabular}


em função dos tratamentos e do extrator utilizado. A capacidade de extração de $P$ em geral foi decrescente na seguinte ordem: Mehlich-1, resina e Olsen (tabela 9).

O extrator Mehlich-1 recuperou mais fósforo do solo que o da Resina e Olsen, para todas as fontes e doses de fósforo aplicadas, com exceção da dose $300 \mathrm{ugP} / \mathrm{g}$ de TER na qual a resina recuperou um pouco mais de fósforo que o Mehlich-1. A maior recuperação do método da resina nessa dose e para essa fonte, deve-se provavelmente, ao fato de o fosfato quando aplicado ao solo ter promovido maior formação de fosfatos ligados a $\mathrm{Ca}(\mathrm{P}-\mathrm{Ca})$, pois os ions fosfatos formados são mais rapidamente transformados em P-Ca e P-Fe do que em P-Al. A tendência do extrator Mehlich de recuperação de fósforo, atribui-se ao fato que esse extrator atua mais intensamente sobre as formas de $\mathrm{P}-\mathrm{Al}$, devido à sua maior acidez (THOMAS \& PEASLEE, 1973). Segundo COPE \& EVANS (1985), o extrator Mehlich-1 é um bom extrator para solos ácidos altamente intemperizados e com baixa CTC.

Os resultados da análise do fósforo recuperado do solo pelos três métodos de extração, após a colheita da parte aérea das plantas de arroz, em função das doses e fontes de adubos fosfatados aplicados, estão apresentados na Tabela 10. De uma forma geral, o extrator Mehlich-1 extraiu mais P que a Resina e o Olsen.

$O$ extrator Mehlich-1 na dose 100 extraiu mais $P$ no tratamento onde foi aplicado FN e foi estatisticamente semelhante ao TER, seguidos pelo SPS, SPT e MAP, para os quais o extrator não apresentou diferenças na extração de P. Na dose 200, o extrator Mehlich-1 extraiu mais P para FN, que foi semelhante ao TER, e este ao SPS e MAP, sendo as menores extrações para SPT que foi estatisticamente semelhante ao MAP. Na dose 300 o extrator Mehlich-1 
Tabela 9 Fósforo recuperado do solo pelos três métodos de extração, 92 días após a aplicação dos adubos fosfatados e produção de material seco da parte aérea das plantas de arroz. Médias de quatro repetições

\begin{tabular}{|c|c|c|c|c|c|}
\hline \multirow[t]{3}{*}{ Fontes } & \multirow{3}{*}{$\begin{array}{l}\text { Doses } \\
\mu \mathrm{gP} / \mathrm{g} \text { solo }\end{array}$} & \multicolumn{3}{|c|}{ Métodos de extração de $\mathrm{P}$} & \multirow{3}{*}{$\begin{array}{l}\text { Mat. seca } \\
\text { g/vaso }\end{array}$} \\
\hline & & Mehlich & Olsen & Resina & \\
\hline & & \multicolumn{3}{|c|}{ - } & \\
\hline \multirow[t]{3}{*}{ FN } & 100 & $71 \mathrm{c}$ & $10 \mathrm{~b}$ & $24 \mathrm{c}$ & $2,87 b$ \\
\hline & 200 & $144 \mathrm{~b}$ & $16 \mathrm{a}$ & $43 \mathrm{~b}$ & $2,98 \mathrm{~b}$ \\
\hline & 300 & $214 a$ & $20 \mathrm{a}$ & $58 \mathrm{a}$ & $3,46 \mathrm{a}$ \\
\hline \multirow[t]{3}{*}{ MAP } & 100 & $35 \mathrm{c}$ & $37 \mathrm{c}$ & $30 \mathrm{c}$ & $3,79 \mathrm{~b}$ \\
\hline & 200 & $110 \mathrm{~b}$ & $66 \mathrm{~b}$ & $68 \mathrm{~b}$ & $4,19 \mathrm{a}$ \\
\hline & 300 & $156 \mathrm{a}$ & $85 a$ & $112 \mathrm{a}$ & $3,05 \mathrm{c}$ \\
\hline \multirow[t]{3}{*}{ SPS } & 100 & $41 \mathrm{c}$ & $32 \mathrm{c}$ & $32 \mathrm{c}$ & $3,40 \mathrm{a}$ \\
\hline & 200 & $114 \mathrm{~b}$ & $52 \mathrm{~b}$ & $66 \mathrm{~b}$ & $3,65 \mathbf{a}$ \\
\hline & 300 & $167 \mathrm{a}$ & $59 a$ & $105 \mathrm{a}$ & $2,95 \mathrm{~b}$ \\
\hline \multirow[t]{3}{*}{ SPT } & 100 & $49 c$ & $35 \mathrm{c}$ & $36 \mathrm{c}$ & $3,60 \mathrm{a}$ \\
\hline & 200 & $88 \mathrm{~b}$ & $61 \mathrm{~b}$ & $72 \mathrm{~b}$ & $3,47 \mathrm{a}$ \\
\hline & 300 & $162 \mathrm{a}$ & $84 a$ & $115 \mathrm{a}$ & $2,89 \mathrm{~b}$ \\
\hline \multirow[t]{3}{*}{$\mathrm{TF}$} & 100 & $87 \mathrm{c}$ & $19 \mathrm{c}$ & $35 \mathrm{c}$ & $3,46 \mathrm{a}$ \\
\hline & 200 & $122 \mathrm{~b}$ & $34 \mathrm{~b}$ & $121 \mathrm{~b}$ & $3,41 \mathrm{a}$ \\
\hline & 300 & $170 \mathrm{a}$ & $54 \mathrm{a}$ & $198 \mathrm{a}$ & 3,33 a \\
\hline Test. & 0 & $2 d$ & $1,6 \mathrm{~d}$ & $3,6 \mathrm{~d}$ & $0,92 \mathrm{c}$ \\
\hline
\end{tabular}

Médias seguidas por letras distintas diferem entre si pelo teste Tukey, ao nível de $5 \%$ de probabilidadde 
Tabela 10. Teor de fósforo recuperado do solo pelos extratores, em função das doses para cada fonte de adubo fosfatado aplicado ao solo, após a colheita das plantas de arroz. Médias de quatro repetições.

\begin{tabular}{|c|c|c|c|c|c|}
\hline \multirow[t]{2}{*}{ Métodos } & \multirow[t]{2}{*}{ Fontes } & \multicolumn{4}{|c|}{ Doses $-\mu \mathrm{P} / \mathrm{g}$ de solo } \\
\hline & & 0 & 100 & 200 & 300 \\
\hline & & \multicolumn{4}{|c|}{ - } \\
\hline \multirow[t]{5}{*}{ Mehlich } & FN & $2,025 \mathrm{~d} \mathrm{~A}$ & $71,40 \mathrm{c} \mathrm{A}$ & 144,25 b A & 213,60 a $A$ \\
\hline & MAP & $1,978 \mathrm{~d} A$ & $35,00 \mathrm{c} \mathrm{B}$ & 109,90 b B C & 155,82 a $B$ \\
\hline & SPS & $2,027 \mathrm{~d} \mathrm{~A}$ & 40,60 c B & $114,10 \mathrm{~b} \mathrm{~B}$ & 167,37 a B \\
\hline & SPT & $2,028 \mathrm{~d} \mathrm{~A}$ & 49,00 c B & 88,20 b C & 161,77 a $B$ \\
\hline & TER & $2,029 \mathrm{~d} \mathrm{~A}$ & 87,50 c $\mathrm{A}$ & 122,15 b A B & 169,85 a $B$ \\
\hline \multicolumn{2}{|c|}{ C.V. $\%=12,81$} & & \multicolumn{3}{|c|}{ D.M.S.: fontes $=11,0967$, doses $=9,3266$} \\
\hline \multirow[t]{5}{*}{ Olsen } & FN & $1,650 \mathrm{c} \mathrm{A}$ & $9,87 \mathrm{~b} \mathrm{C}$ & 15,72 a D & 20,37 a D \\
\hline & MAP & $1,653 \mathrm{~d} \mathrm{~A}$ & 36,62 c A & $65,75 \mathrm{~b} \mathrm{~A}$ & 84,57 a $\mathrm{A}$ \\
\hline & SPS & $1,656 \mathrm{~d} \mathrm{~A}$ & 31,70 с A & 52,42 b B & 59,40 a B \\
\hline & SPT & $1,659 \mathrm{~d} \mathrm{~A}$ & $32,25 \mathrm{c} \mathrm{A}$ & $60,77 \mathrm{~b} \mathrm{~A}$ & 83,57 a $A$ \\
\hline & TER & $1,663 \mathrm{~d} \mathrm{~A}$ & $19,00 \mathrm{c} \mathrm{B}$ & $34,54 \mathrm{~b} \mathrm{C}$ & 53,60 a C \\
\hline \multicolumn{2}{|c|}{ C.V. $\%=7,97$} & & \multicolumn{3}{|c|}{ D.M.S.: fontes $=2,6618$, doses $=2,2372$} \\
\hline \multirow[t]{5}{*}{ Resina } & FN & $3,587 \mathrm{~d} \mathrm{~A}$ & $23,89 \mathrm{c} \mathrm{A}$ & $42,70 \mathrm{~b} \mathrm{C}$ & 58,04 a C \\
\hline & MAP & $3,585 \mathrm{~d} \mathrm{~A}$ & 29,75 c A & $68,07 \mathrm{~b} \mathrm{~B}$ & 112,44 a B \\
\hline & SPS & $3,588 \mathrm{~d} \mathrm{~A}$ & $32,46 \mathrm{c} \mathrm{A}$ & $66,41 \mathrm{~b} \mathrm{~B}$ & 105,09 a $\mathrm{B}$ \\
\hline & SPT & $3,589 \mathrm{~d} \mathrm{~A}$ & 36,22 c A & 71,83 b B & 115,94 a B \\
\hline & TER & $3,586 \mathrm{~d} \mathrm{~A}$ & $34,96 \mathrm{c} \mathrm{A}$ & 129,69 b A & 197,75 a A \\
\hline \multicolumn{2}{|c|}{ C.V. $\%=12,75$} & & \multicolumn{3}{|c|}{ D.M.S.: fontes $=7,1953$, doses $=6,0475$} \\
\hline
\end{tabular}

Médias seguidas por letras maiúsculas distintas na vertical ou letras minúsculas distintas na horizontal, diferem entre si pelo teste Tukey ao nível de $5 \%$ de probabilidade. 
extraiu mais P para FN. seguido dos adubos TER, SPS, SPT e MAP que foram estatisticamente semelhantes.

O extrator Olsen na dose 100 , extraiu mais $P$ no tratamento com MAP, que foi estatisticamente semelhante ao SPT e ao SPS, seguido do TER e menos para FN. Na dose 200 extraiu mais $\mathrm{P}$ para o MAP, que foi semelhante ao SPT, seguidos dos adubos SPS, TER e FN, para os quais o P extraído com este extrator não apresentou diferença significativa, na dose 300 o comportamento deste extrator foi semelhante ao da dose 200.

O extrator resina, para a dose 100 não apresentou diferenças na extração de $\mathrm{P}$ para as cinco fontes de adubos fosfatados. Na dose 200 extraiu mais P para o TER, seguido de SPT, MAP, e SPS, em que o P extraído não apresentou diferenças significativas já para o FN nessa dose a resina extraiu menos $\mathrm{P}$. Na dose 300 o comportamento desse extrator foi semelhante ao da dose 200 .

A Tabela 11 apresenta o resultado das análises de variância do fósforo extraído pelos três extratores em função das doses de $\mathrm{P}$, dentro de cada fonte de adubo fosfatado aplicado ao solo, mostrando efeitos altamente significativos para a extração de $\mathrm{P}$ pelos extratores, para as doses, fontes e a interação fontes $\mathrm{x}$ doses.

As figuras 4, 5, 6, 7 e 8 relacionam o fósforo adicionado ao solo na forma dos diferentes adubos fosfatados, com o $\mathrm{P}$ extraído pelos extratores. Quando se adicionou $\mathrm{FN}$, os três extratores tiveram efeitos lineares altamente significativos na extração de P. Quando se adicionou MAP o extrator Mehlich-1 teve efeito linear altamente significativo e os extratores Olsen e Resina apresentaram efeitos quadráticos altamente significativos. Quando se adicionou 
SPS os extratores Mehlich-1 e Resina apresentaram efeito linear altamente significattivo e o extrator Olsen efeito quadrático altamente significativo. Finalmente, quando se adicionou SPT e TER o efeito dos extratores foi semelhante.

As figuras 9, 10 e 11 correlacionam o fósforo extraído pelos extratores entre si, e os coeficientes revelam boa significância, mostrando que houve certa semelhança na extração de $\mathrm{P}$, sendo a melhor correlação estabelecida entre os extratores Mehlich-1 e Resina $\left(r^{2}=0,81\right)$.

\subsection{Resposta do arroz ao fósforo recuperado pelos extratores}

Na Tabela 9 relacionou-se o $\mathrm{P}$ disponível, extraído pelos três métodos com a produção de material seco da parte aérea das plantas de arroz e o comportamento para cada fonte de adubo fosfatado foi o seguinte:

Fosfato natural Alvorada (FN): para essa fonte de fósforo, a extração de fósforo foi elevada pelo método de Mehlich, enquanto os métodos Resina e Olsen extrairam-no em quantidades menores. Houve acréscimo na produção de material seco até os valores máximos extraídos pelos três métodos. Estes resultados são um tanto diferentes dos obtidos por SFREDO et al. (1979), pois segundo esses pesquisadores o extrator Olsen extraiu mais fósforo que o Mehlich-1, seguramente porque nesse trabalho, as condições foram diferentes das aquí apresentadas.

Monofosfato de amônio (MAP): para essa fonte o comportamento dos extratores foi semelhante ao do FN na produção de material seco, mas acima 
de $200 \mathrm{ugP} / \mathrm{g}$ aplicado ao solo, passa a provocar um efeito negativo na produção de material seco.

\section{Superfosfato simples(SPS), Superfosfato triplo (SPT) e} termofosfato (TER): o comportamento dos extratores para essas fontes foi semelhante ao do MAP na produção de material seco, e da mesma forma, a dose $200 \mathrm{ugP} / \mathrm{g}$ aplicado ao solo, provocou decréscimo na produção de material seco.

As figuras 12, 13 e 14 apresentam as correlações que foram altamente significativas entre o extrator Mehlich-1 e a produção de material seco $\left(\mathrm{r}^{2}=0,91\right)$, porcentagem de $\mathrm{P}\left(\mathrm{r}^{2}=0,86\right)$ e $\mathrm{P}$ absorvido pela parte aérea das plantas de arroz $\left(\mathrm{r}^{2}=0,88\right)$. As figuras 15,16 e 17 apresentam as correlações altamente signifcativas entre o extrator Olsen e a produção de material seco $\left(r^{2}=0,94\right)$, porcentagem de $\mathrm{P}\left(\mathrm{r}^{2}=0,91\right)$ e $\mathrm{P}$ absorvido pela parte aérea das plantas de arroz $\left(r^{2}=0,93\right)$. As figuras 18,19 e 20 apresentam as correlações altamente significativas entre o extrator Resina e a produção de material seco $\left(r^{2}=0,87\right)$, porcentagem de $\mathrm{P}\left(\mathrm{r}^{2}=0,91\right)$ e $\mathrm{P}$ absorvido pela parte aérea das plantas de arroz $\left(r^{2}=0,93\right)$. Observa-se que o método Olsen apresentou uma tendencia de correlação melhor que os métodos Mehlich-1 e Resina, porém sua capacidade de extração de $\mathrm{P}$ do solo é mais baixa, como já foi discutido. Resultados semelhantes foram encontrados por KOCHHANN et al. (1982), porém a Resina também apresentou boa correlação com a resposta do arroz a 0 fósforo aplicado, resultado que concorda com RAIJ et al.(1984) 
Tabela 11. Análise de variância do fósforo extraído pelos três métodos de extração em função das doses para cada fonte de adubo fosfatado aplicado ao solo

\begin{tabular}{|c|c|c|c|c|}
\hline Causas da variação & G.L. & S.Q. & Q.M. & Valor F \\
\hline \multicolumn{5}{|l|}{ Mehlich } \\
\hline Fonte & 4 & 12890,4666 & 3222,6166 & $25,9102 * *$ \\
\hline Dose & 3 & 329584,9580 & 109861,6527 & $883,2997^{* *}$ \\
\hline Fonte $\mathrm{x}$ Dose & 12 & 9956,8669 & 829,7389 & $6,6712 * *$ \\
\hline Residuo & 60 & 7462,5848 & 124,3764 & \\
\hline Total & 79 & 359894,8762 & & \\
\hline \multicolumn{2}{|c|}{ Media geral $=87,0306$} & \multicolumn{3}{|c|}{ Coeficiente de variação $=12,81 \%$} \\
\hline \multicolumn{5}{|l|}{ Olsen } \\
\hline Fonte & 4 & 13451,0721 & 3362,7680 & $469,8920 * *$ \\
\hline Dose & 3 & 38718,1139 & 12906,0379 & $1803,4086 * *$ \\
\hline Fonte $\mathrm{x}$ Dose & 12 & 6608,2709 & 550,6892 & $76,9499 * *$ \\
\hline Residuo & 60 & 429,3881 & 7,1565 & \\
\hline Total & 79 & 59206,8451 & & \\
\hline \multicolumn{2}{|c|}{ Media geral $=33,5829$} & \multicolumn{3}{|c|}{ Coeficiente de variação $=7,97 \%$} \\
\hline \multicolumn{5}{|l|}{ Resina } \\
\hline Fonte & 4 & 27207,4631 & 6801,8658 & $130,0713 * *$ \\
\hline Dose & 3 & 149893,5626 & 49964,5208 & $955,4658 * *$ \\
\hline Fonte $\mathrm{x}$ Dose & 12 & 26834,0255 & 2236,1688 & $42,7620 * *$ \\
\hline Residuo & 60 & 3137,6018 & 52,2934 & \\
\hline Total & 79 & 207072,6529 & & \\
\hline \multicolumn{2}{|c|}{ Media geral $=56,7095$} & \multicolumn{3}{|c|}{ Coeficiente de variação $=12,75 \%$} \\
\hline
\end{tabular}




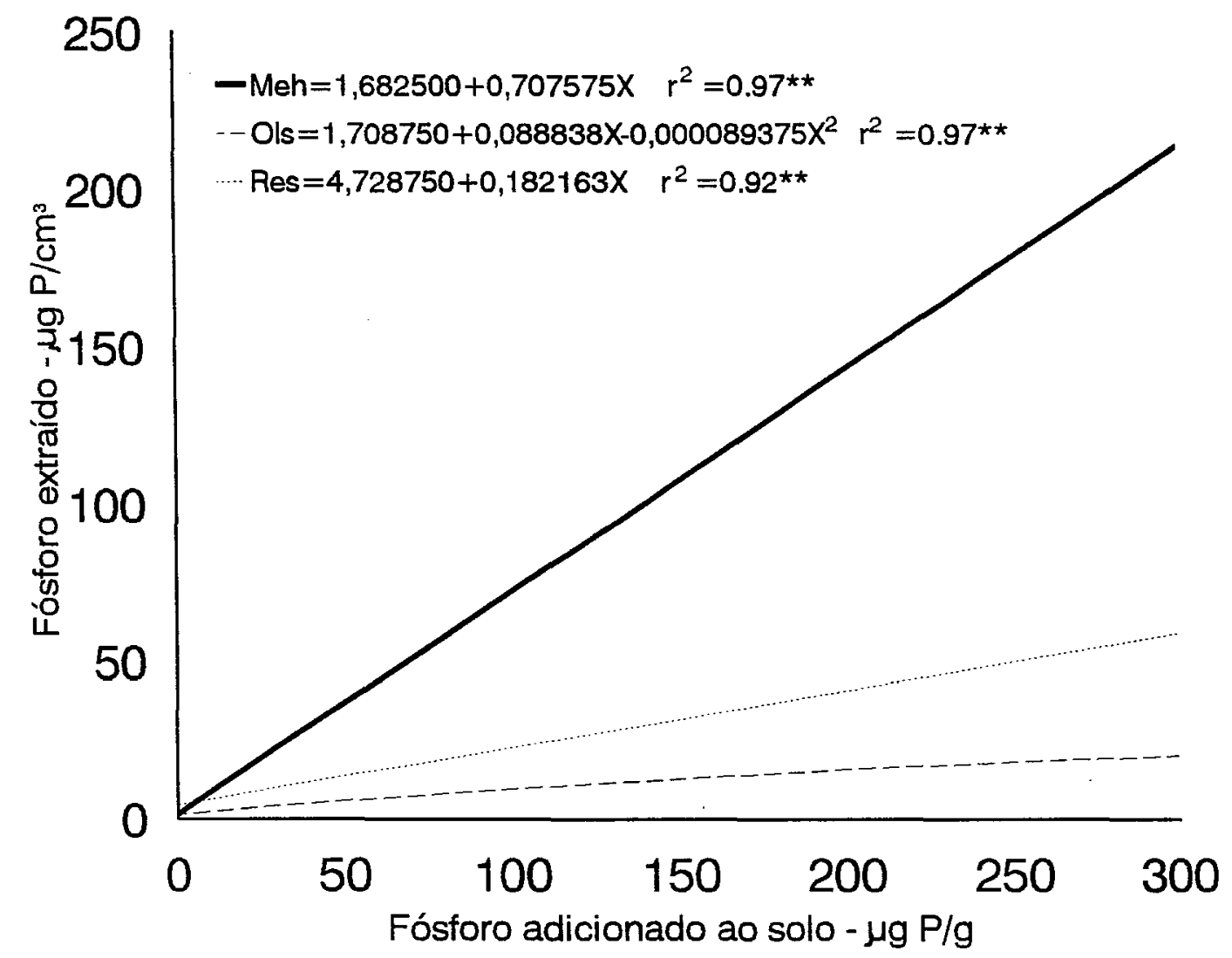

Figura 4. Correlações estabelecidas entre as doses de fósforo adicionado ao solo na forma de fosfato natural-Alvorada (FN) e o fósforo recuperado pelos extratores Mehlich-1, Olsen e Resina 


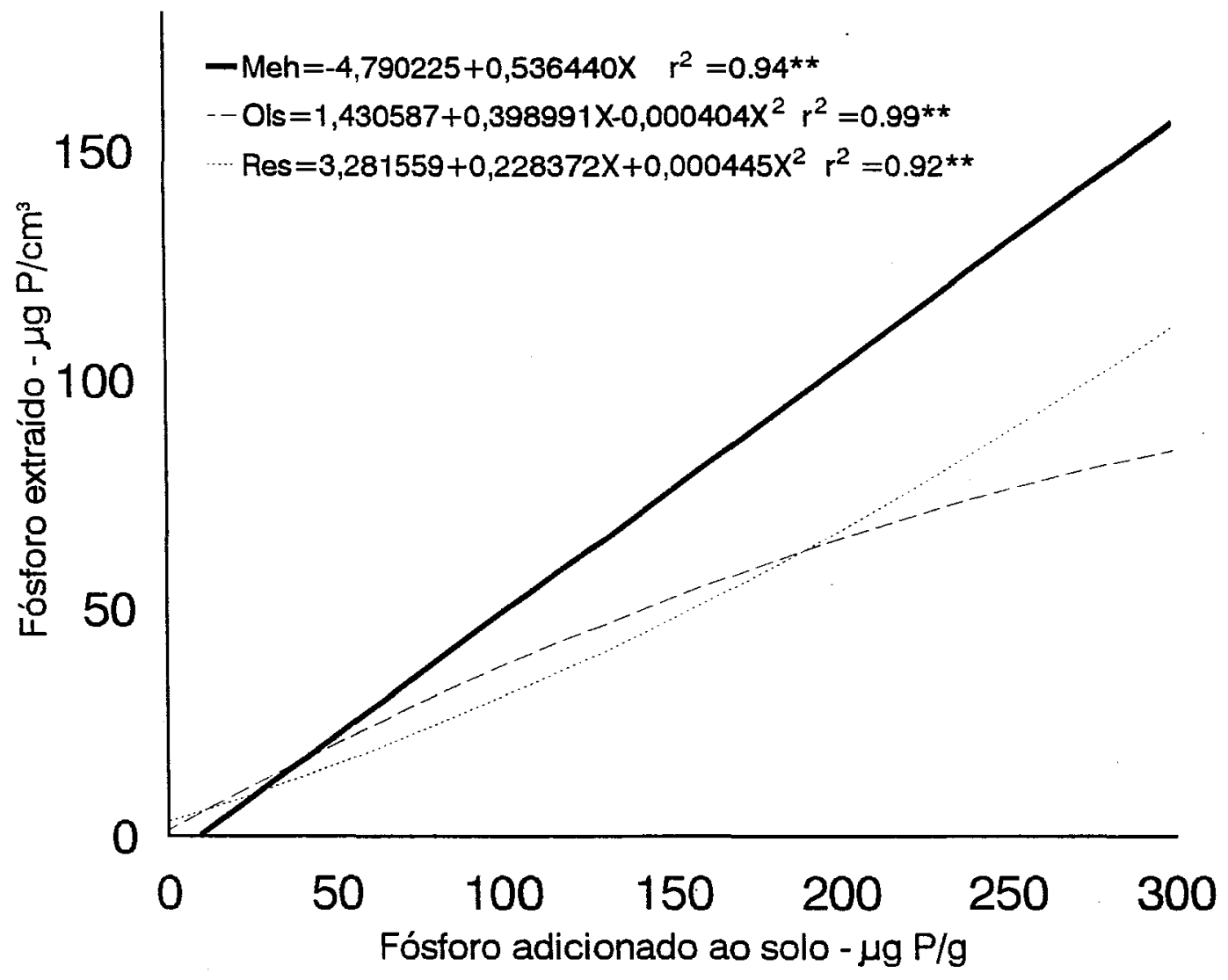

Figura 5. Correlações estabelecidas entre o fósforo adicionado ao solo na forma de monofosfato de amônio (MAP) e o fósforo recuperado pelos extratores Mehlich-1, Olsen e Resina 


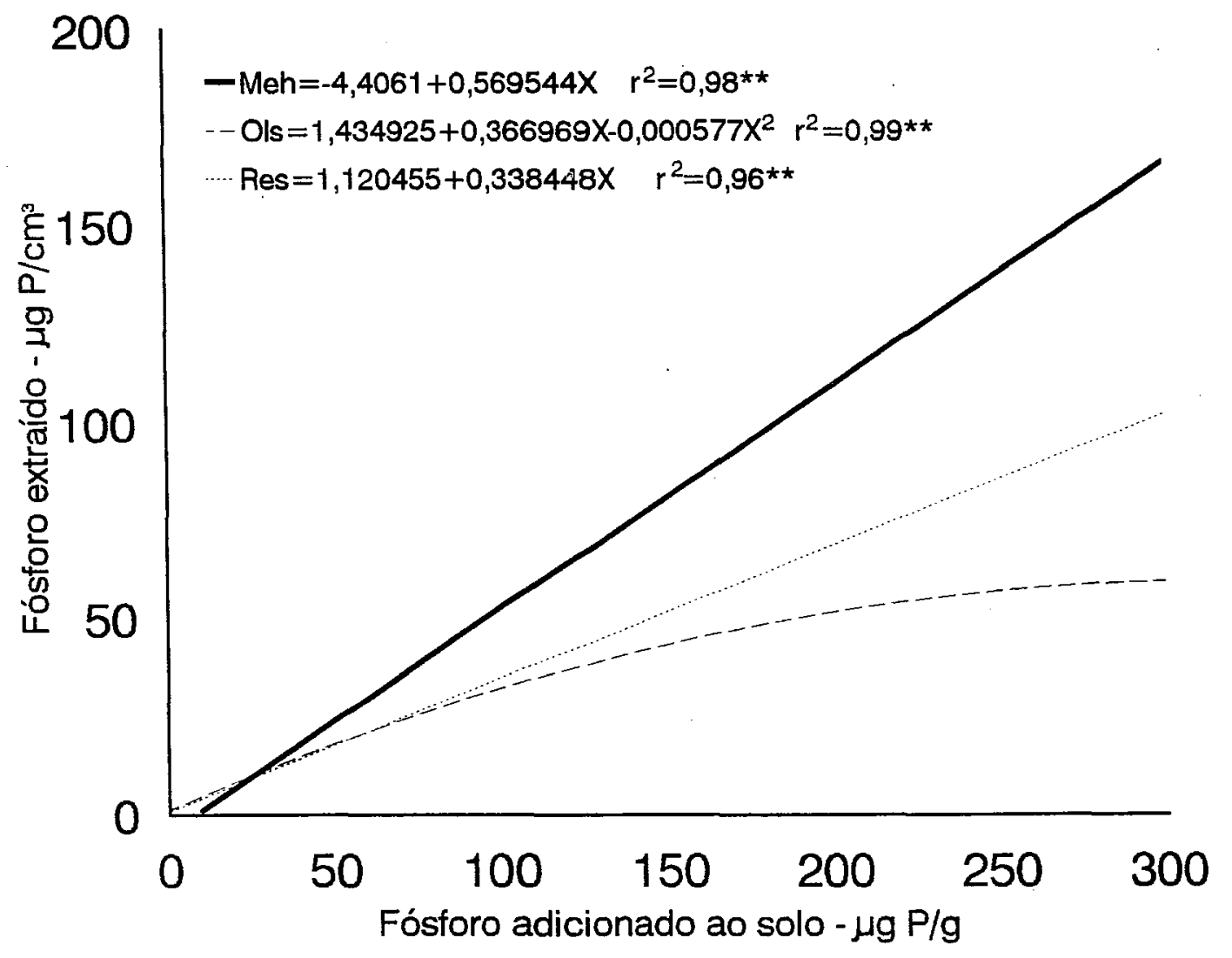

Figura 6. Correlações estabelecidas entre o fósforo adicionado ao solo na forma de superfosfato simples (SPS) e o fósforo recuperado pelos extratores Mehlich-1, Olsen e Resina 


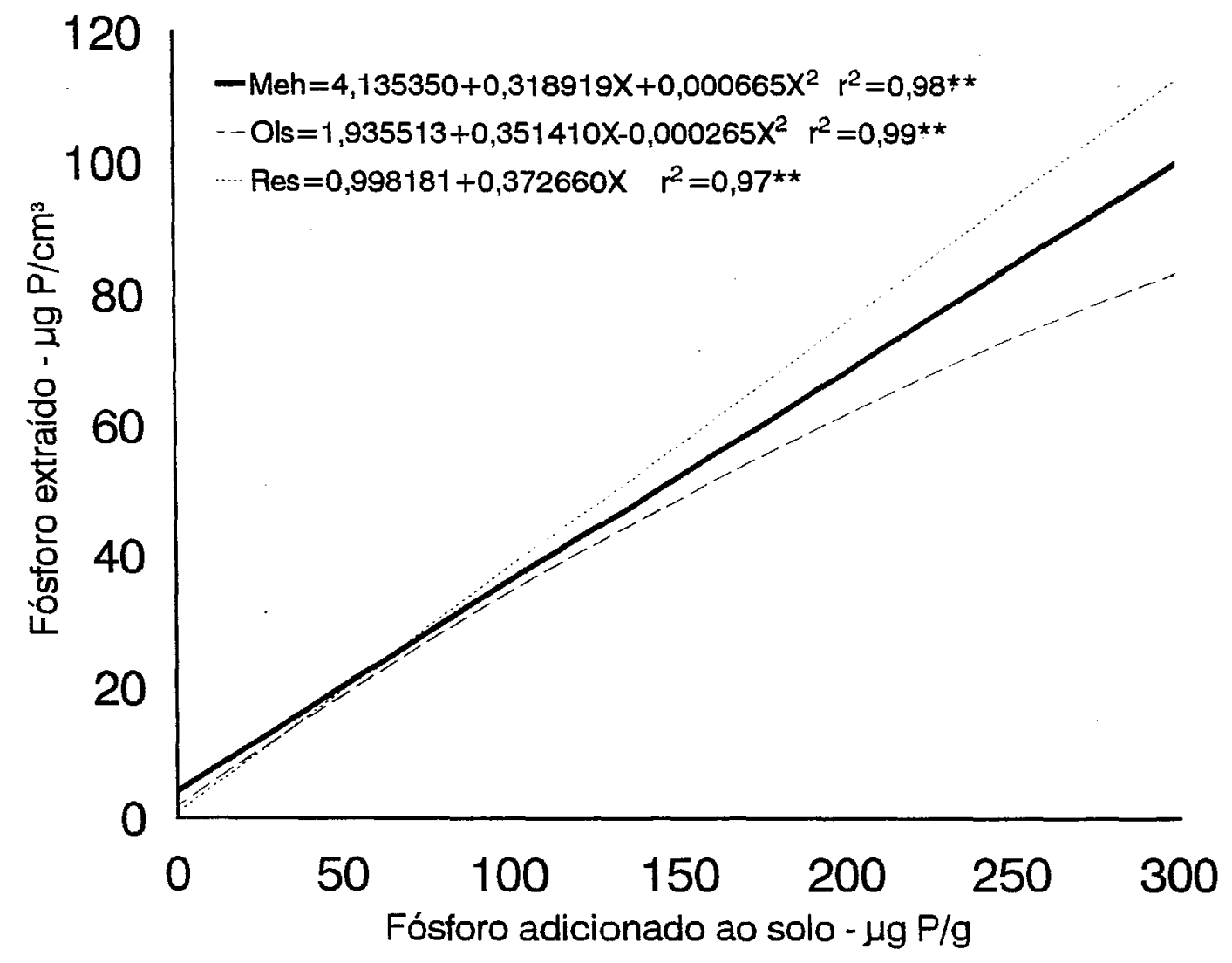

Figura 7. Correlações establecidas entre o fósforo adicionado ao solo na forma de superfosfato triplo (SPT) e o fósforo recuperado pelos extratores Mehlich-1, Olsen e Resina 


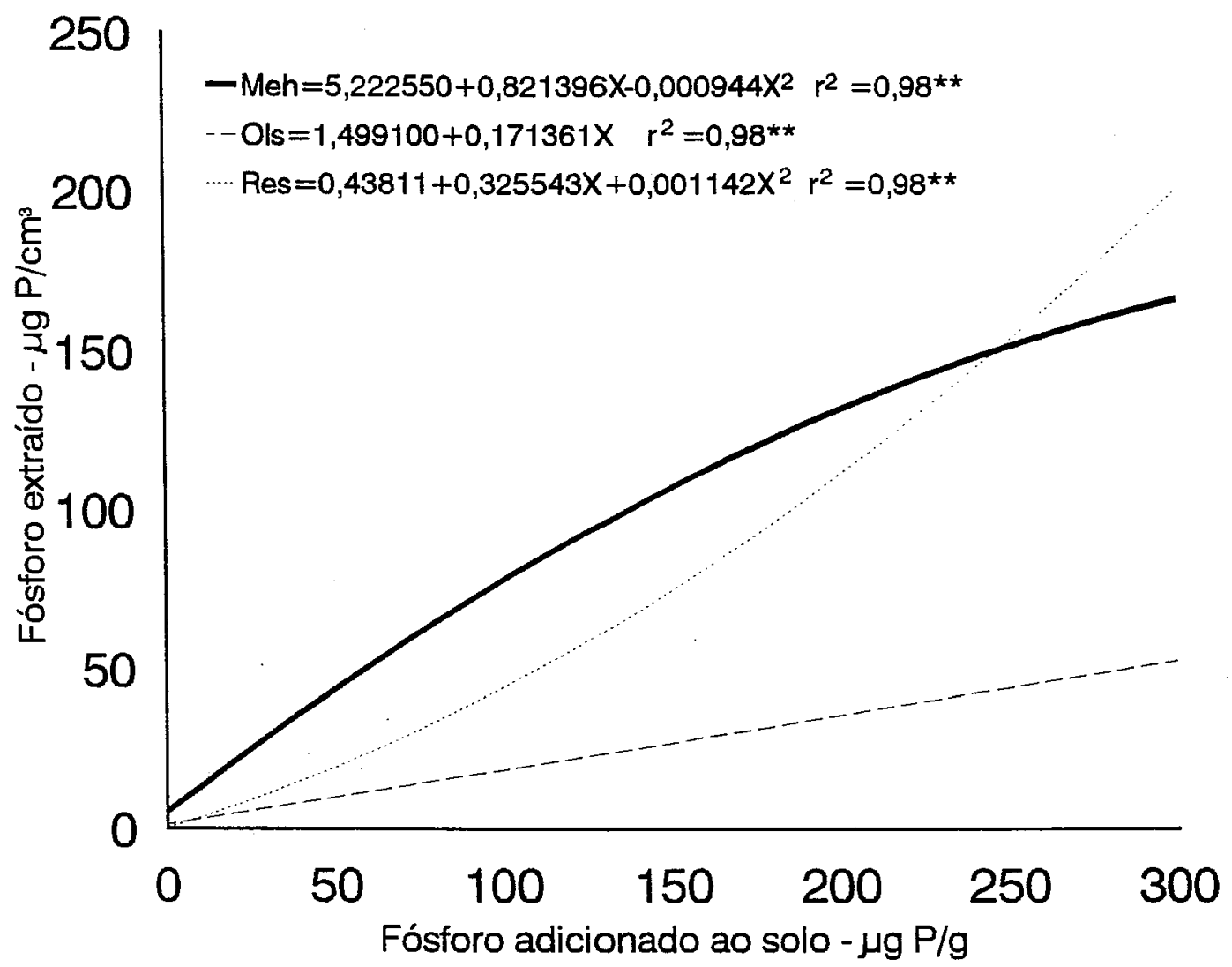

Figura 8. Correlações estabelecidas entre o fósforo adicionado ao solo em três doses de $\mathrm{P}$ na forma de termofosfato-Yoorin (TER) e o fósforo recuperado pelos extratores Mehlich-1, Olsen e Resina 


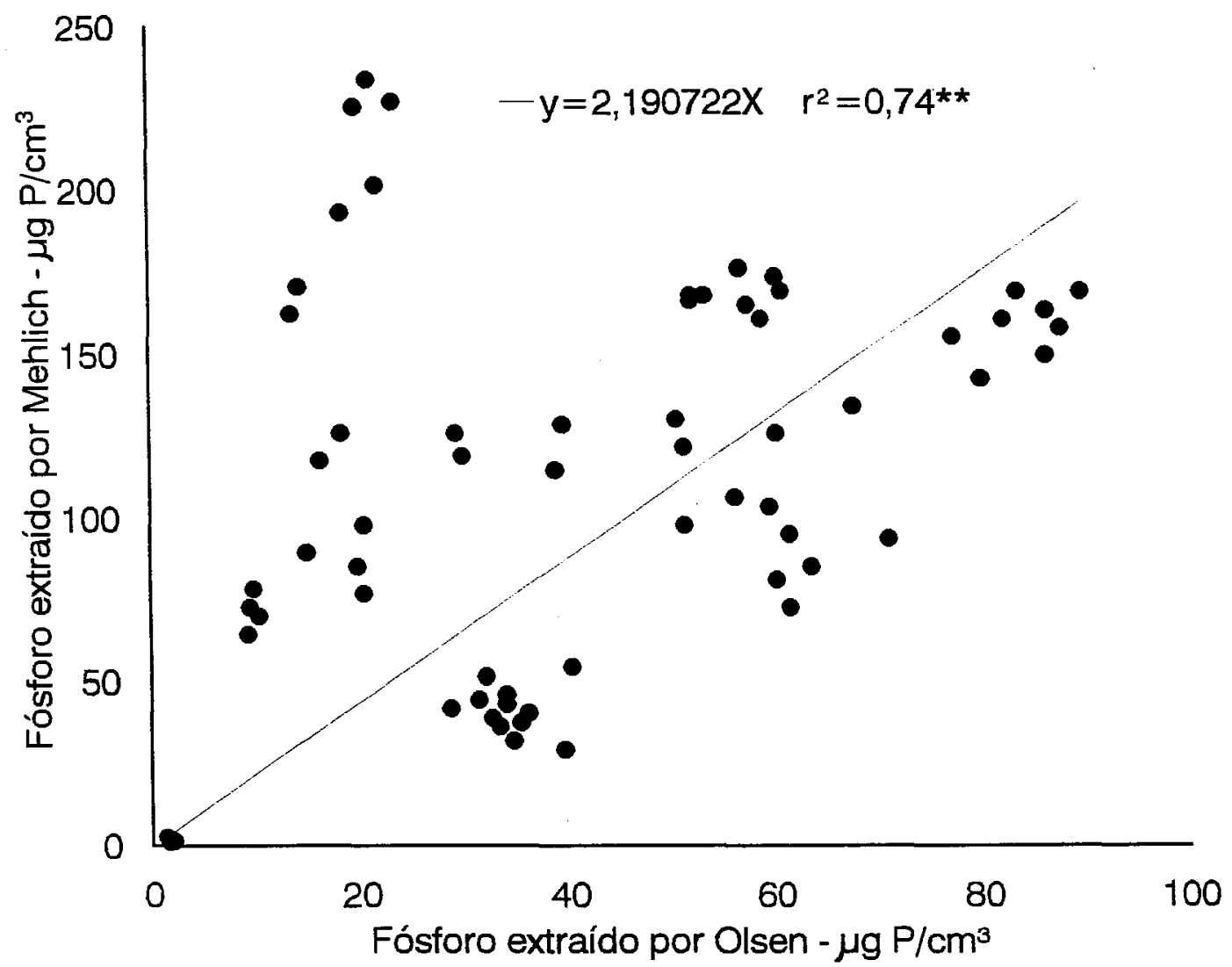

Figura 9. Correlação estabelecida entre o fósforo recuperado do solo pelos extratores Mehlich-1 e Olsen 


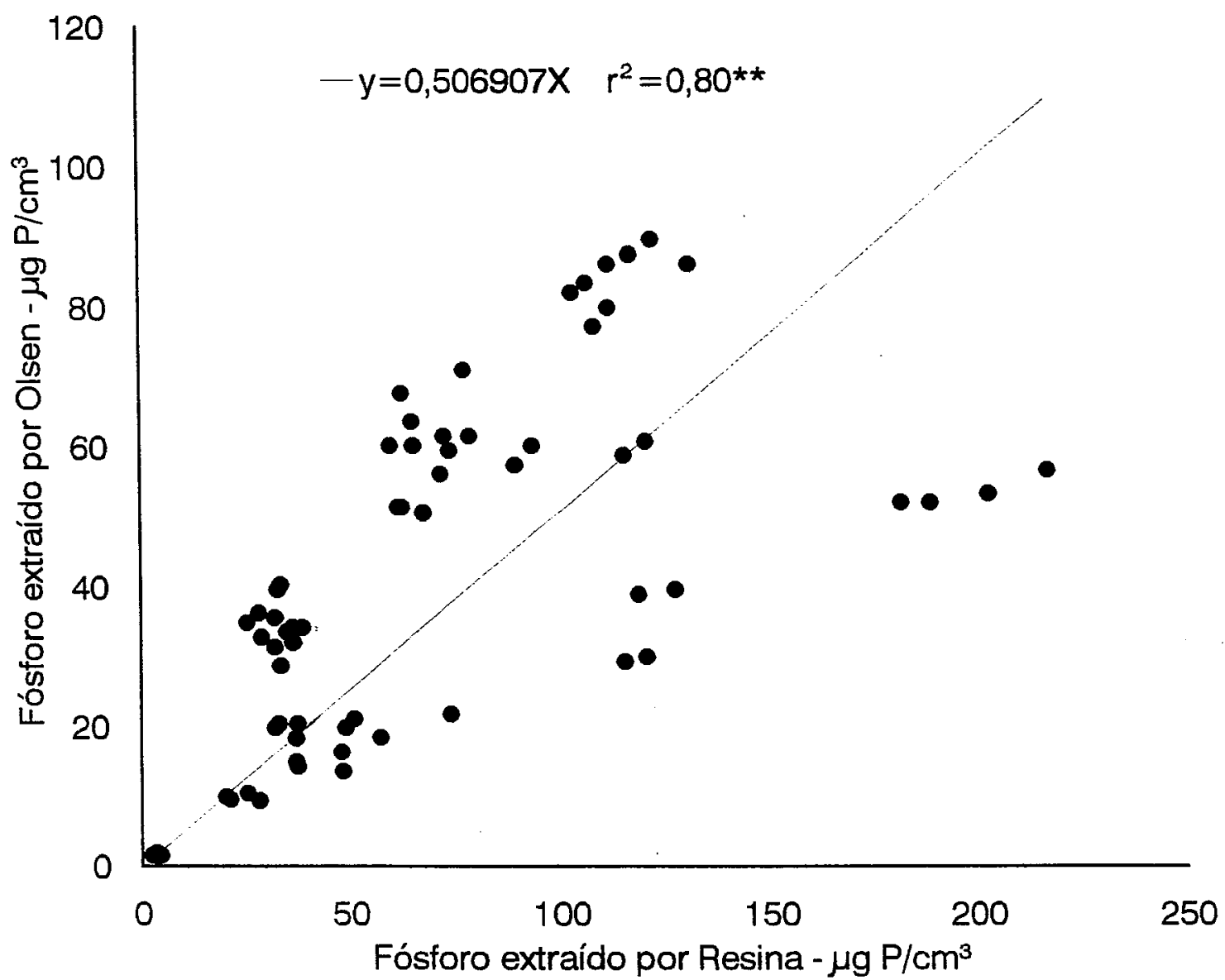

Figura 10. Correlação estabelecida entre o fósforo recuperado do solo pelos extratores Olsen e Resina 


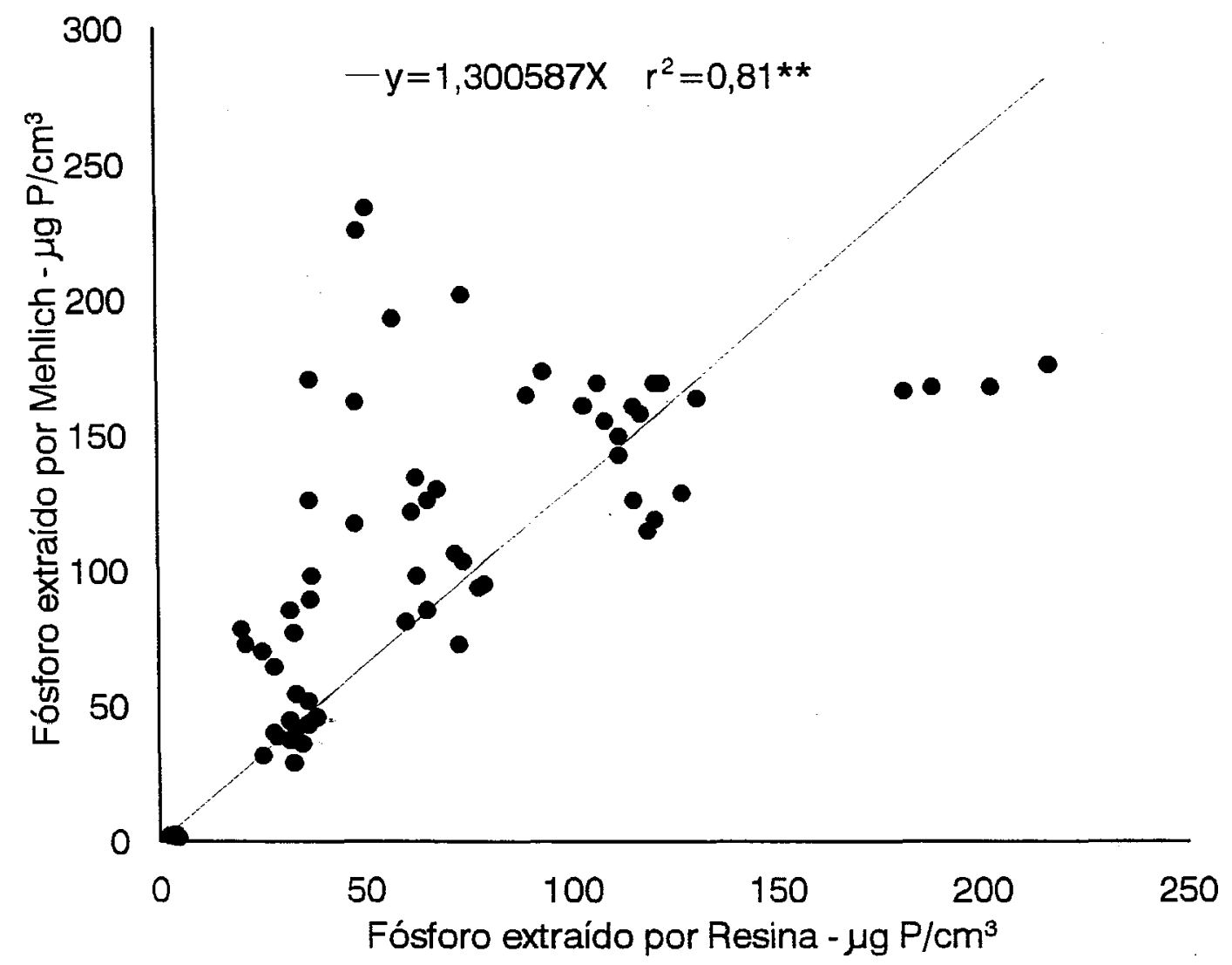

Figura 11. Correlação estabelecida entre o fósforo recuperado do solo pelos extratores Mehlich-1 e Resina 


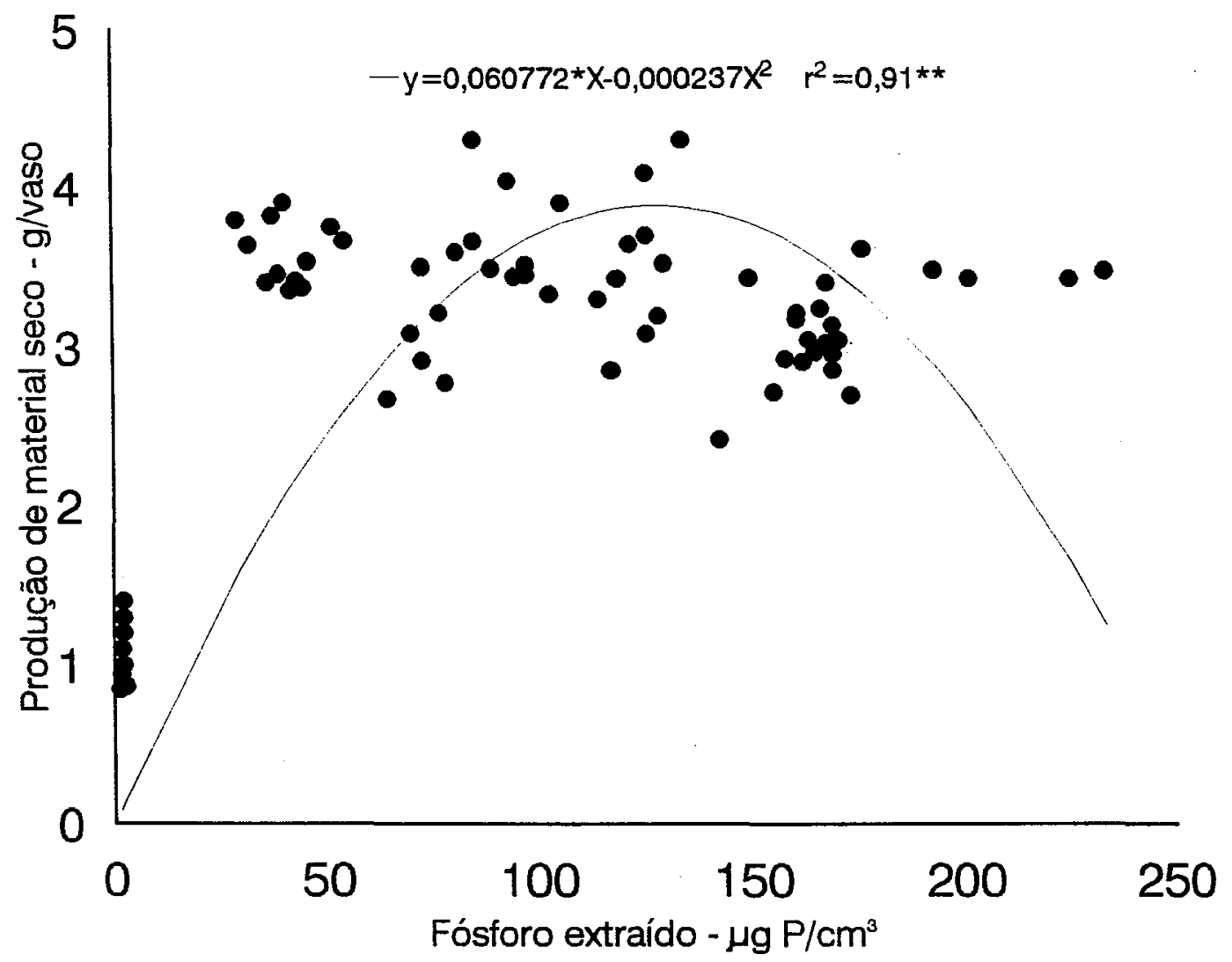

Figura 12. Correlação estabelecida entre o fósforo recuperado do solo pelo extrator Mehlich-1 e produção de material seco da parte aérea das plantas de arroz 


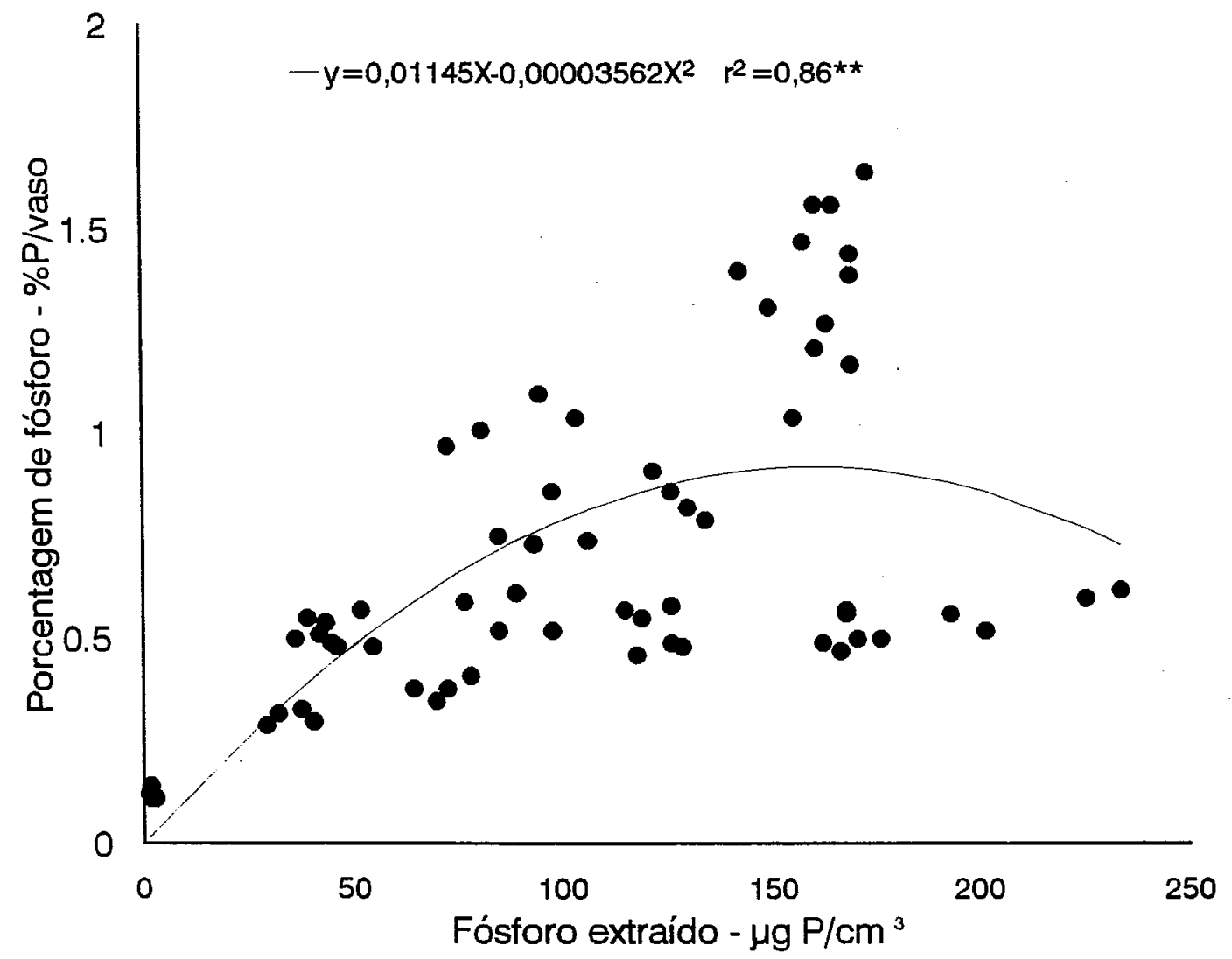

Figura 13. Correlação estabelecida entre o fósforo recuperado do solo pelo extrator Mehlich-1 e o porcentagem de $\mathrm{P}$ na parte aérea das plantas de arroz 


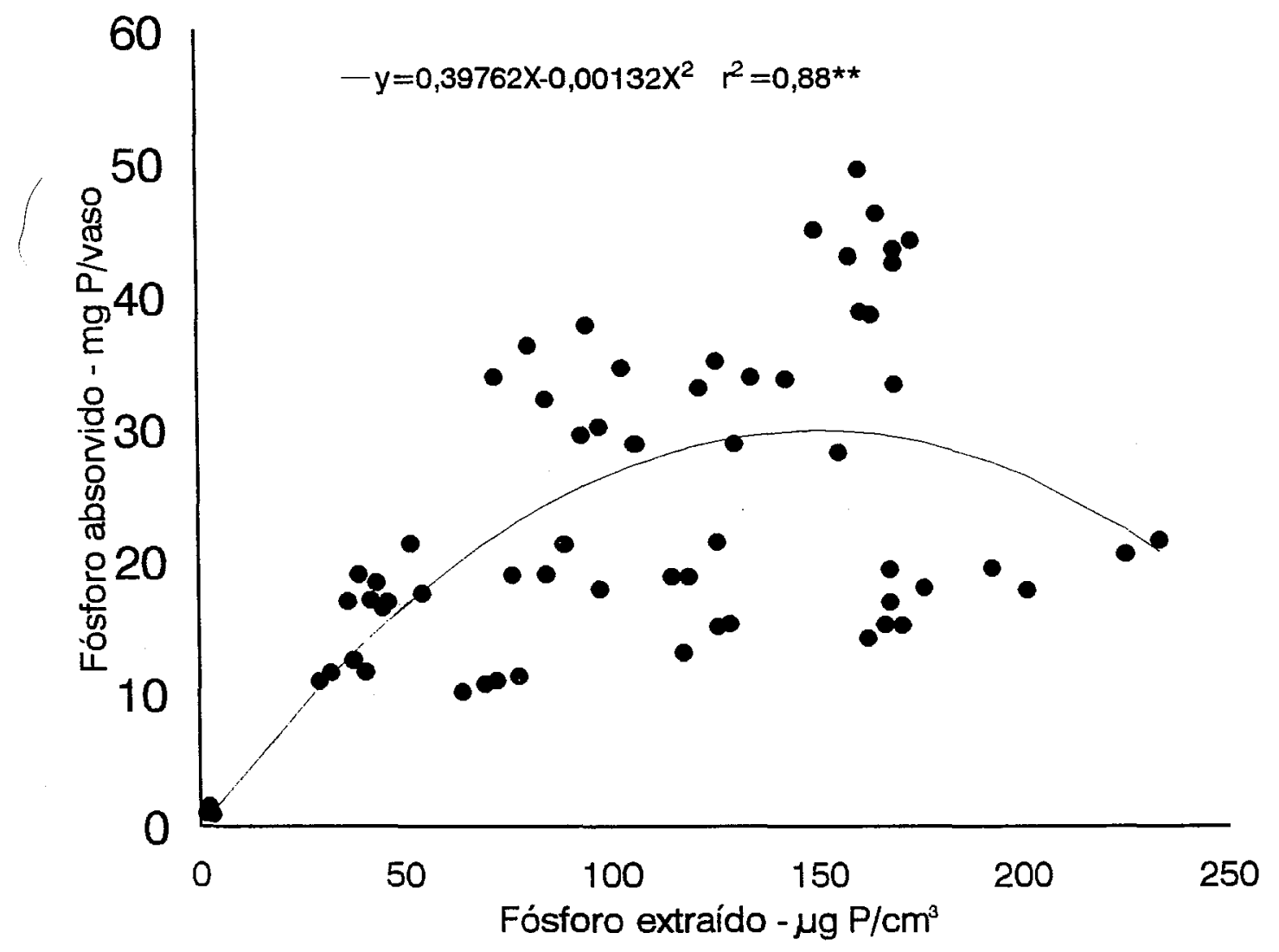

Figura 14. Correlação estabelecida entre o fósforo extraído do solo pelo extrator Mehlich-1 e o P absorvido pela parte aérea das plantas de arroz 


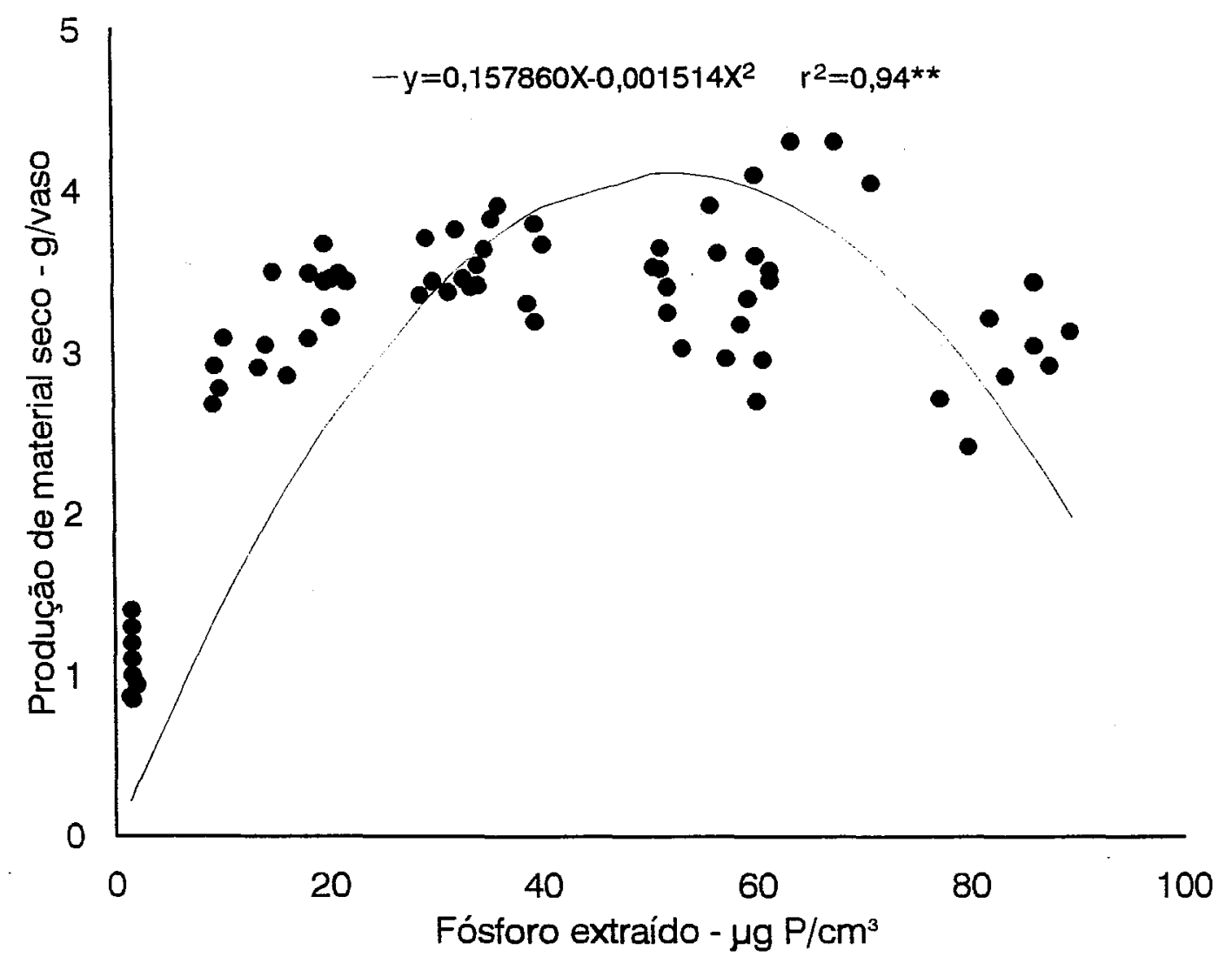

Figura 15. Correlação estabelecidaa entre o fósforo recuperado do solo pelo extrator Olsen e a produção de material seco pela parte aérea das plantas de arroz 


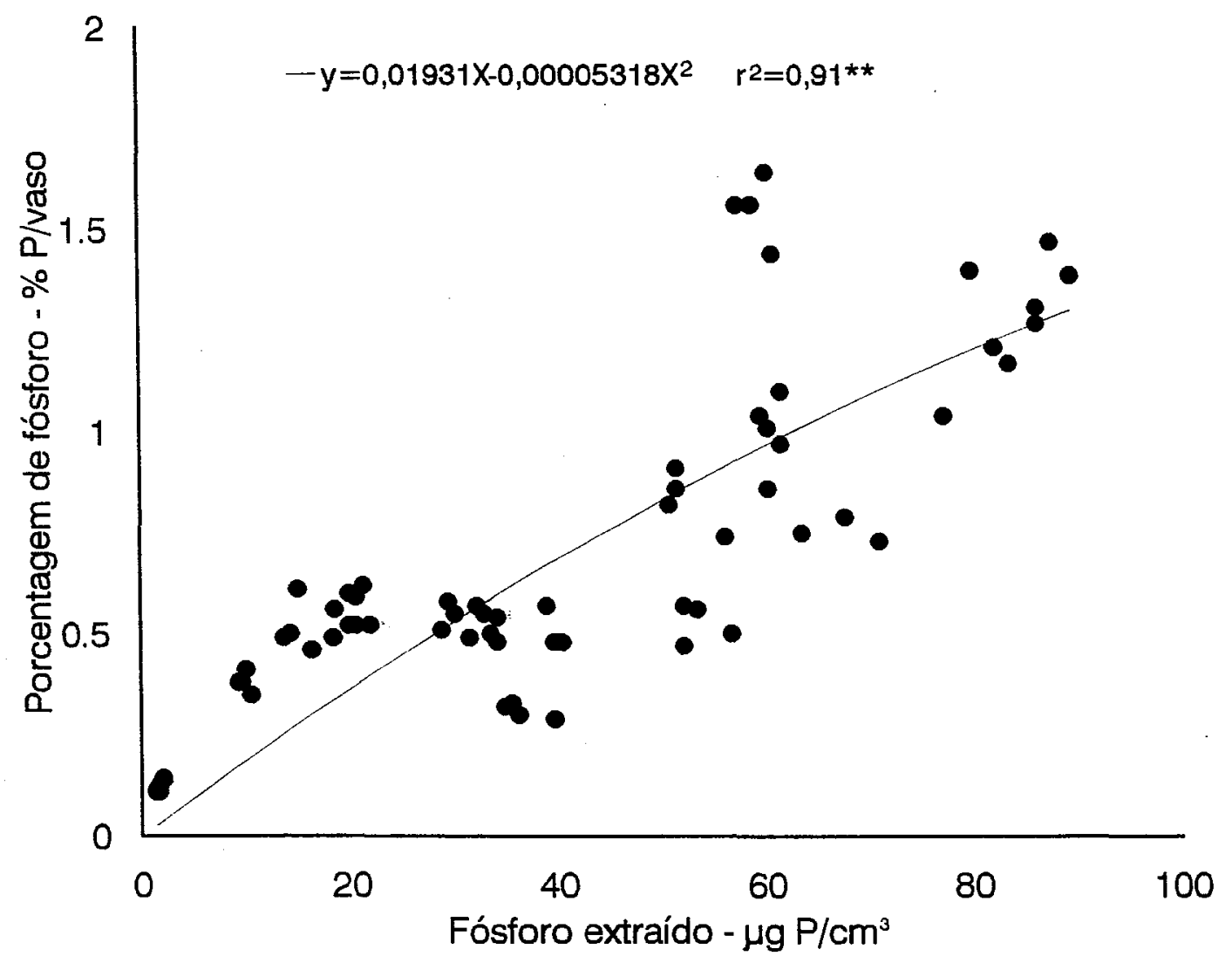

Figura 16. Correlação estabelecida entre o fósforo recuperado do solo pelo extrator Olsen e o porcentagem de $\mathrm{P}$ no material seco 


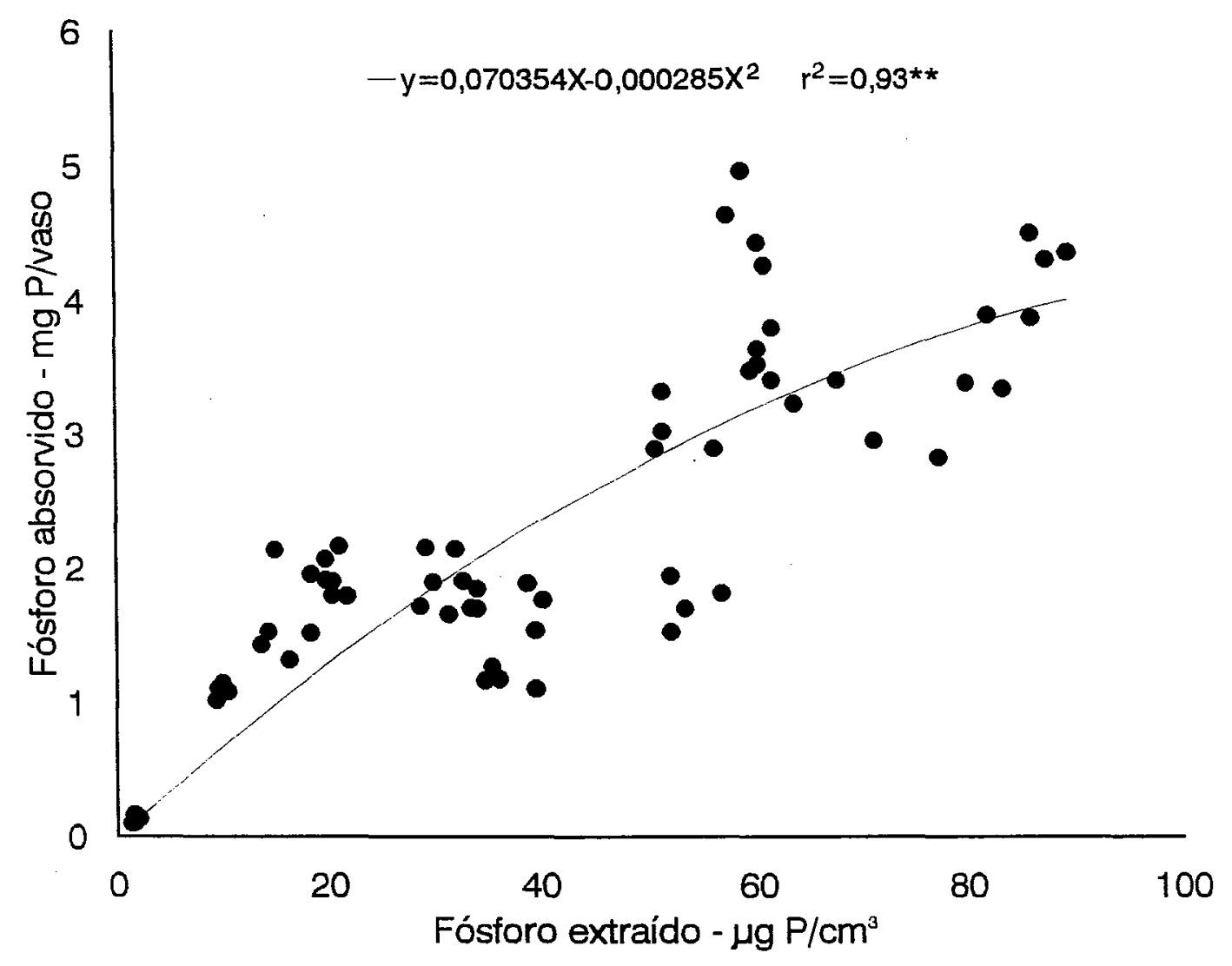

Figura 17. Correlação estabelecida entre o fósforo recuperado do solo pelo extrator Olsen e o P absorvido pela parte aérea das plantas de arroz 


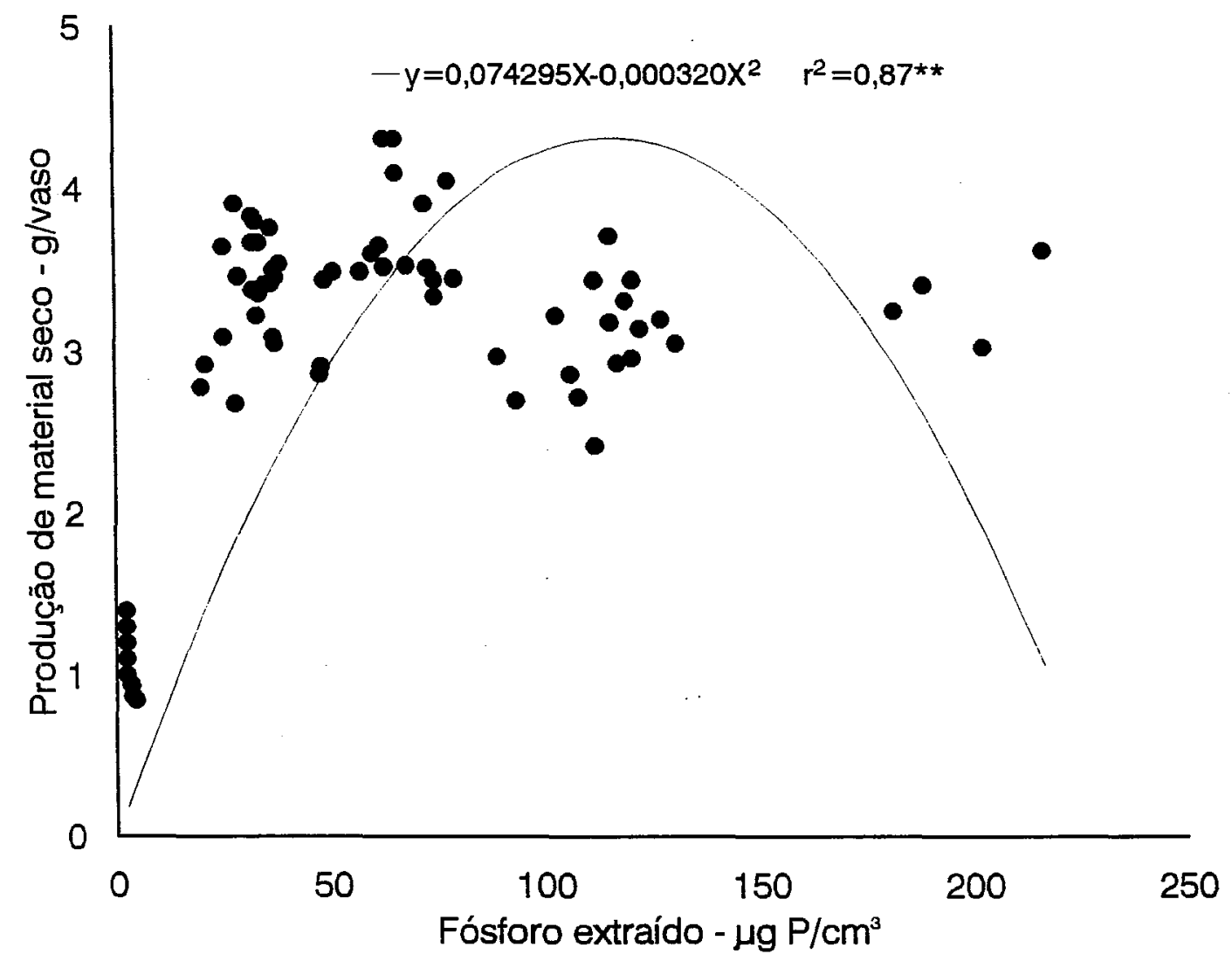

Figura 18. Correlação estabelecida entre o fósforo recuperado do solo pelo extrator Resina e a produção de material seco pela parte aérea das plantas de arroz 


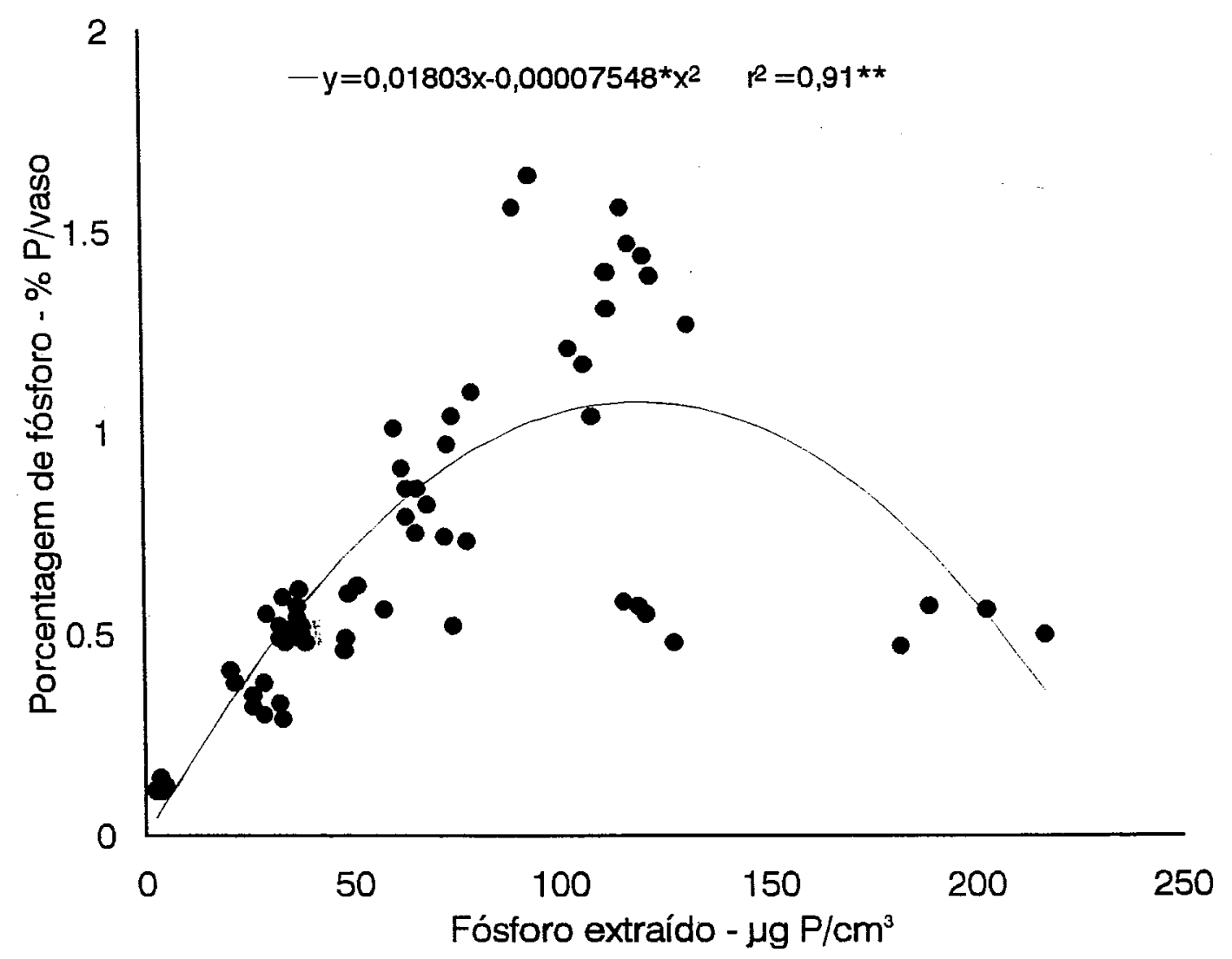

Figura 19. Correlação estabelecida entre o fósforo recuperado do solo pelo extrator Resina e o porcentagem de fósforo no material seco 


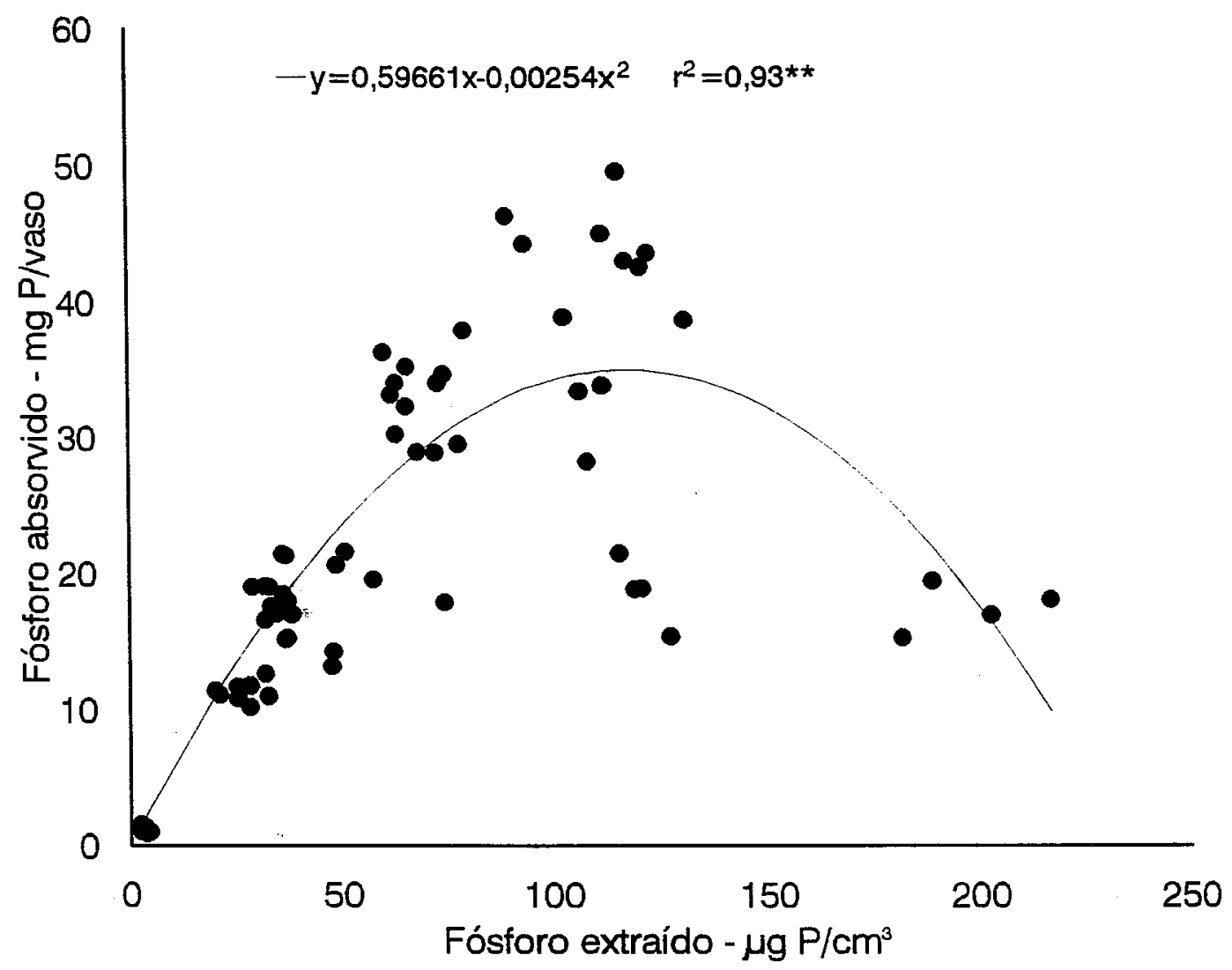

Figura 20. Correlação estabelecida entre o fósforo recuperado do solo pelo extrator Resina e o fósforo absorvido pela parte aérea das plantas de arroz 


\section{CONCLUSÕES}

Nas condições em que foi realizado o experimento, os resultados obtidos permitem concluir que:

- As fontes de fósforo utilizadas comportaram-se de forma diferente em relação aos extratores do solo.

- Os adubos termofosfato, superfosfato simples e superfosfato triplo aumentaram o $\mathrm{pH}$ do solo.

- O extrator Mehlich-1 extraiu mais fósforo que o de Olsen e a Resina, porém a melhor correlação com a resposta do arroz às fontes e doses de fósforo, deu-se com o extrator Olsen

- A dose $200 \mu \mathrm{gP} / \mathrm{g}$ de solo, foi suficiente para atingir a máxima resposta do arroz, em termos de material seco e $\mathrm{P}$ absorvido, para todas as fontes testadas

- Os adubos monofosfato de amônio e superfosfato simples na dose $200 \mu \mathrm{gP} / \mathrm{g}$ de solo proporcionaram o maior peso de material seco da parte aérea nas plantas de arroz, os adubos superfosfato triplo e termofosfato o fizeram na dose $100 \mu \mathrm{gP} / \mathrm{g}$ de solo. Para o fosfato natural, o incremento de produção de material seco foi crescente em função das doses aplicadas ao solo. 
- Os teores de fósforo nas plantas de arroz foram mais elevados para os tratamentos que receberam monofosfato de amônio e superfosfato simples na dose $300 \mu \mathrm{gP} / \mathrm{g}$ de solo.

- Os três extratores utilizados correlacionaram-se com a resposta do arroz às doses de fósforo para todas as fontes de adubos fosfatados 


\section{REFERÊNCIAS BIBLIOGRÁFICAS}

ADAMS, J.F. \& ODOM, J.N. Effects of $\mathrm{pH}$ and phosphorus rates on soilsolution phosphorus and phosphorus availability. Soil Science, 140: 202-5, 1985.

ALCARDE, J.C.; GUIDOLIN, J.A.; LOPES, A.S. Os adubos e a eficiência das adubaçoes. São Paulo, ANDA, 1990. 35p.

AZEVEDO FILHO, A.J.B.V.; FRANCO Jr., C.F.; MELLO F.A.F. de; ARZOLLA, S. Efeitos de três adubos fosfatados sobre a acidez de dois solos do município de Piracicaba. Anais. ESALQ/USP, Piraicaba, 45(2): $479-98,1988$.

BARBOSA FILHO, M.P.; KINJO, T.; MURAOKA, T. Relações entre fósforo extraído, frações inorgânicas de fósforo e crescimento do arroz em função de fontes de fósforo, calagem e tempo de incubação. Revista Brasileira de Ciência do solo, 11: 147-55, 1987.

BRAGA, N.R.; MASCARENHAS, H.A.A.; BULISANI, E.A.; RAIJ, B. van FEITOSA, C.T.; HIROCE, R. Eficiência agronômica de nove fosfatos em quatro cultivos consecutivos de soja. Revista Brasileira de Ciência do Solo. Campinas, 15:315-9, 1991.

CABALA, R.P. \& SANTANA, M.B.M. Influência do tempo de contato com o solo do valor fertilizante de fontes fosfatadas. In: CONGRESSO BRASILEIRO DE CIÊNCIA DO SOLO, XIX, Curitiba, Resumos, 1983. $126 \mathrm{p}$. 
CHIEN, S.H. Disoolution of phosphate rocks in a flooded acid soil. Soil Science Society American Journal, Madison, 41: 565-65.7, 1977.

COELHO, F.S. \& VERLENGIA, F. Fertilidade do solo. 2.ed. Campinas, ICEA, 1973. 384p.

COOKE, G.W. The control of soil fertility. London, Crosby Lockwood \& Son. 1967. p.122-138.

COPE, J.T. \& EVANS, C.E. Soil testing. Adv in Soil Science, 1:201-288, 1985.

COREY, R.B. Factors affecting the availability of nutrients to plants. In: WALSH, L.M. \& BEATON, J.A. Soil testing and plant analysis. 2a. ed. Madison, Soil Science Society of American, 1973. p.23-34.

CORREAA, L. de A. \& HAAG, H.P. Disponibilidade de fósforo pelos exratores de Mehlich-1 e Resina em Latossolo Vermelho Amarelo, Álico cultivado com três gramíneas forrageiras. Scientia Agrícola. Piracicaba, 50(2): 28794, 1993.

COSTA, A. Uso de fertilizantes na cultura do arroz. In: INSTITUTO AGRONÔMICO DO PARANÁ. Londrina - PR. Uso de fertilizantes na agricultura paranaense. Londrina. 1980. p.61-7 (circular 16).

EKPETE, D.M. Evaluation of chemical methods for the determnation of available phosphorus in waterlogged soils. Soil Science. Baltimore, 121:21721,1976

FAGERIA, N.K. Adubação e nutrição da cultura do arroz irrigado. Goiânia, Campus/ EMBRAPA, 1984. 341p. 
FEITOSA, C.T. Avaliação da disponibilidade do fósforo aplicado ao solo na forma de diferentes fosfatos. Piracicaba, ESALQ/USP. 1978. 81p. (Mestrado - Escola Superior de Agricultura "Luiz de Queiroz" / USP).

FERNANDES, F.M.; FERREIRA, M.E.; MELHO, F.A.F. de. Fontes e doses de adubos fosfatados na cultura da soja em solo de cerrado. Anais. ESALQ/USP, Piraicaba, 41(2):655-74, 1984.

FERNANDES, F.M.; FERREIRA, M.E.; MELHO, F.A.F. de. Comparação de extratores de fósforo do solo, considerando-se o tempo de incorporação de fontes de adubos fosfatados. Anais. ESALQ/USP, Piracicaba, 41(2):67588. 1984(a).

GARGANTINI, H. \& C.T. FEITOSA. Comportamento de diferentes fertilizantes fosfatados, em diversas condições de acidez do solo em dois grupos de solo do Estado de SãoPaulo. In: CONGRESSO BRASILEIRO DE CIÊNCIA DO SOLO, 16, Santa Maria, R.S., 1973. Anais. Santa Maria, UFSM, Soc. Bras. Ciência do Solo. 1974. p.256-262.

GARGANTINI, H. \& SANTOS, D. Competição de fertilizantes fosfatados em soja. Bragantia. Campinas, 30:117-24, 1971.

GOEDERT, W.J. \& LOBATO, E. Eficiência agronômica de fosfatos em solos de cerrado. Pesquisa Agropecuária Brasileira. Brasilia, 15(3):311-18, 1980.

GOEDERT, W.J.; J.F. PATELLA; J.F.V. MORAIS. Formas de fósforo num Planosolo do rio Grande do Sul e sua disponibilidade para a cultura do arroz irrigado. Pesquisa Agropecuária Brasileira., Ser.Agron. 6:39-43. 1971.

GOEDERT, W.J.; REIN, T.A. SOUSA, D.M.G. Eficiência agronômica de fosfatos naturais,fosfatos parcialmente acidulados e termofosfatos em solos de cerrado. Pesquisa Agropecuária Brasileira. Brasilia, 25(4):521-30, 1990. 
GOEDERT, W.J. \& SOUSA,D.M.G. Uso eficiente de fertilizantes fosfatados. In: SIMPÓSIO SOBRE FERTILIZANTES NA AGRICULTURA BRASILEIRA, 14. Anais. Brasilia, EMBRAPA, 1984. p.255-89.

GRANDE, M.A.; CURI, N.; QUAGGIO, J.A. Disponibilidade de fósforo pelos extratores de Mehlich e Resina, em solos cultivados com arroz irrigado. Revista Brasileira de Ciência do Solo. Campinas, 3(2):100-5, 1986.

INSTITUTO DE PESQUISAS TECNOLÓGICAS. Tecnologia de produção de fertilizantes, São Paulo, 1990. 237p.

JORGE, J.A. \& J. VALADARES. Formas de fósforo em solos do Estado de São Paulo. Bragantia, 28 (2):23-30. 1969.

KAMPRATH, E.J WATSON, M.E. Conventional soil and tissue tests for assessing the phosphorus status of soils. In: KHASAWNEH, F.E.; SAMPLE, E.C.; KAMPRATH, E.J. The role of phosphorus in agriculture. Madison, American Societyof agronomy, 1980. p.433-69.

KOCHHANN, R.; ANGHINONI, I.; MIELNICZUK, J. Adubação fosfatada no Rio GRande do Sul e Santa Catarina. In: OLIVEIRA, A.J.; LOURENÇO, S.; GOEDERT, W.J. Adubação fosfatada no Brasil. Brasília, EMBRAPA / DID, 1982. p.29-60.

LEHR, J.R. \& . McLELLAN, G.H. Arevised laboratory reativity scale evaluating phosphate rocks for direct aplication. Muscle Shoals, Alabama, National Fertilizer Develoment Center. 1972. 36p. (Bulletin, y-43).

LOPES, A.S. Manual de fertilidade do solo. São Paulo, ANDA/POTAFOS. 1989. 153P. 
LOURENÇO, S. Adsorção e dessorção do fósforo em solos do estado do Paraná. Piraciacaba, 1971. 69p. (Doutorado - Escola Superior de Agricultura "Luiz de Queiroz" / USP).

MACHADO, M.O. Caracterização e adubação do solo. In: EMBRAPA. Fundamentos para a cultura do arroz irrigado. Fundação Cargil. Campinas, 1985. p.129-179.

MALAVOLTA, E. Elementos de nutrição mineral de plantas. Ed. Agronômica, CERES, 1980. 251p.

MALAVOLTA, E. Adubos e adubação fosfatada. São Paulo, Fertilizantes MITSUI, 1985. 61p.

MALAVOLTA, E.; VITTI, G.C.; ALCARDE, J.C.; ROSOLEM, C.A.; FORNASIERI Fo., D. Aproveitamento de um fosfato natural parcialmente solubilizado pelas culturas do arroz, milho e soja. Anais, ESALQ/USP, Piracicaba, 38 (2): 801-18. 1981.

MALAVOLTA, E.; VITTI, G.C.; OLIVEIRA, S.A. Avaliação do estado nutricional das plantas: Principios e aplicações. Piracicaba. Associação Brasileira para Pesquisa da Potassa e do Fosfato, 1989. 201p.

MANDAL, L.N. \& DAS, R.K. Transformation of applied water soluble phosphate in acidic lowland rice soils. Soil science., 111: 263-7, 1970.

MELLO, F.A.F.; ARUTR, V.; VICTORIA, R. Efeito de três adubos fosfatados sobre a acidez de um solo hidromórfico. Revista de Agricultura, 56 (4): 301-11, 1981.

MELLO, F.A.; BELLONI, E.; JANKOVSKI, F.; KOFFLER, N.; VALERIO, F.M. Efeito do tratamenti de um latossolo com fosfato sobre a capacidade de fixação do mesmo. Revista de agricultura, Piracicaba, 55(3): 127-31, 1980. 
MENGEL, K. \& KIRKBY, E.A. Principles of plant nutrition. 4. ed. Berna, International Potash Institute, 1987. 687p.

MORAES, J.F.V. Efeitos da inundação do solo. II. Influência sobre a absorção de nutrientes e o crescimento do arroz (Oriza sativa L.). Pesquisa Agropecuária Brasileira, 8:103-8, 1973.

MORAIS, O.P. \& GONTIJO, V.de P.M. Resposta da cultura do arroz (Oriza sativa L.) de sequeiro a fertilização NPK e a calagem. Projeto Arroz, Anual 75/76. Belo Horizonte. 1978 p.93-146.

MOREIRA, J.F. Cinética de transformação de P-lábil em não lábil, por análise química e crescimento de mudas de eucalipto. Viçosa, 1988. 52p. (Mestrado-Universidade Federal de Viçosa).

NELSON, W.L.; MEHLICH, A.; WINTERS, E. The development, evaluation and use of soil tests phosphorus availability. In: PIERRE, W.H. \& NORMAN, A.G. (ed.). Soil and fertilizer phosphorus. Agronomy. 4: 89$122,1953$.

NEPTUNE, A.M.L. \& PEREZ, A.J.L. Disponibilidade de fóforo e correlações entre formas e quantidades absorvidas pelo feijoeiro (Phaseolus vulgaris L.) em solos do Estado de São Paulo. Anais. ESALQ/USP, Piracicaba, 44 (1): 769-80. 1987

NOVAIS, R.F.; BRAGA, J.M.; MARTINS Fo., C.A.S. Efeito do tempo de incubação de fosfato de Araxá em solos sobre o fósforo disponível. Revista Brasileira de Ciência do solo. Campinas, 4: 153-5, 1989.

NOVELINO, J.O.; NOVAIS, R.F.; NEVES, J.C.L.; COSTA, L.M.; BARROS, N.F. Solubilização de fosfato-de-araxá, em diferentes tempos de incubação, com amostras de cinco latossolos, na presença e na ausência de calagem. Revista Brasileira de Ciência do Solo. 9:13-22, 1985. 
OLIVEIRA, O.F. de; CAMARGO, C.E.O.; RAMOS, V.J. Efeito do fósforo sobre os componentes de produção, altura das plantas e rendimento de grãos, em trigo. Bragantia, Campinas, 43(1): 31-44. 1984.

OLSEN, S.R.; COLE, C.V.; WATANABE, F.S.; DEAN, L.A. Estimation of available phosphorus in soils ny extraction with sodium bicarbonate. USDA Circ. 939:1-19, 1954.

PATRICK Jr., W.H. \& MAHAPATRA, I.C. Transformation and availabilityto rice of nitrogen and phosphorus in waterlogged soil. Advances of Agronomy, Madison. 20: 223-59, 1968

PONNAMPERUMA, F.N. Dinamic aspects of flooded soils. In: INTERNATIONAl RICE RESERS INSTITUTE. (ed.) The mineral nutrition of the rice plant. Baltimore, Johns Hopkins Press, 1964. p.295-328.

RAIJ, B. van. Seleção de métodos de laboratório para avaliar a disponibilidade de fósforo em solos. Revista Brasileira de Ciência do Solo, 2(1): 1-9, 1978.

RAIJ, B. van. Fertilizantes fosfatados e uso. Informações agronômicas. 26, Piracicaba, Potafos, 1984.

RAIJ, B. van. Fertilidade do solo e adubação. São Paulo/ Agronômica Ceres, Piracicaba, Potafos, 1991. 343p.

RAIJ, B. van; C.T. FEITOSA; SILVA, N.M. da. Comparação de quatro extratores de fósforo de solos. Bragantia, Campinas, 43: 17-29. 1984.

RAIJ, B. van. \& QUAGGIO, J.A. Métodos de análise de solos para fins de fertilidade. Campinas, Instituto Agronômico, 1983. 31p. (IAC, Boletim Técnico, 81). 
RAIJ, B. van.; ROSAND, P.C.; LOBATO, E. Adubação fosfatada no Brasil: apreciação geral, conclusões e recomendações. In: OLIVEIRA, A.J.; LOURENÇO, S. GOEDERT, W.J. Adubação fosfatada no Brasil. Brasilia, EMBRAPA / DID, 1982. p.289-98.

REZENDE, J.O. Capacidade de fixação do fósforo por solos dos estados da Bahia e Sergipe. Influência do pH e tempo de reação. Piracicaba, 1974. 81p. (Mestrado - Escola Superior de Agricultura "Luiz de Queiroz" / USP)

ROJAS, W.C. Seleccción de métodos para la evaluación de fósforo disponível en suelos arroceros. Agricultura Técnica. 36: 5-13, 1976.

SALGADO, A.L. B de; A. AZZINI; C.T. FEITOSA; A. PETTINELLI; G. de. Efeito de fertilizantes fosfatados na cultura da crotálaria. Bragantia, Campinas, 43(1):1-8. 1984.

SEATZ, L.; STAMBERRY F.; CANNEY, O. Advances in phosphate fertilization. In: McVICKAR, M.H.; BRIDGER NELSON, L.B. Fertilizer tecnology and usage. Madison, Soil Science Society of América, 1963. p.155-80.

SFREDO, G.J.; BORKERT, C.M.; CORDEIRO,D.S.; PALHANO, J.B.; DITTRICH, R.C. Comparação de cinco extratores de fósforo do solo, considerando-se o tempo de incorporação de três adubos fosfatados. Revista Brasileira de Ciência do solo, 3: 111-5, 1979.

SOUZA, M.A. de; MORAIS, O.P. de; TAKAHASHI, C. Adubação N P K na cultura do trigo (Triticum aestivum L.), Proj. Trigo Rel. Anual 75/76, Belo Horizonte. 1978. p.51-6.

SYERS, J.K. \& MACKAY, A.D. Reactions of Sechura phosphate rock and single superphophate in soil. Soil Science Society of American Journal, Madison, 50(2):480-5, 1986. 
THOMAS, G.W. \& PEASLEE, D.E. Testing soils for phosphorus. In: WALSH, L.M.; BEATON, J.D., ed. Soil testing and plant analysis. Madison, Soil Science Society of América, 1973. p.115-29.

VIEGAS, G.P.; FREIRE, E.S.; CONAGIN, A. NAGIN, A. Adubação de milho. XVIII. Ensaios de diversos fosfatos (4a serie). Bragantia. Campinas, 20(1):;1-13, 1961.

VOLKWEIS, S.J. \& RAIJ, B. van. Retenção e disponibilidade de fósforo em solos. In: SIMPÓSIO SOBRE O CERRADO: BASES PARA UTILIZAÇÃO AGROPECUÁRIA, 4., Brasilia, 1976. Anais. São Paulo, EDUSP, 1977. 